\title{
John Locke, Toleration, and Samuel Parker's A Discourse of Ecclesiastical Politie (1669): A New Manuscript
}

\author{
J. C. Walmsley ${ }^{*}$ (D) and Felix Waldmann ${ }^{* *}$ \\ ${ }^{\star}$ Independent scholar and ${ }^{*}$ Christ's College, Cambridge \\ Corresponding author. E-mail: j_c_walmsley@hotmail.com \\ Corresponding author. E-mail: few23@cam.ac.uk
}

(Received 16 January 2021; revised 22 April 2021; accepted 20 June 2021)

The following article prints a new manuscript by John Locke: a commentary on A Discourse of Ecclesiastical Politie (1669) by Samuel Parker (1640-88), the religious controversialist. Locke's interest in Parker's work has been known to scholars since 1954, when notes by Locke of roughly one thousand words were purchased by the Bodleian Library. The article reports the discovery of an unknown portion of this commentary: a manuscript of roughly three thousand words in the University of North Carolina at Chapel Hill. The article transcribes the manuscript, reconstructs its provenance, and reexamines Locke's engagement with Parker's Discourse. This engagement occurred in the period following Locke's composition of the first recensions of his Essay Concerning Toleration (1667-8), as Locke contemplated a refutation of Parker's ecclesiology. The discovered manuscript provides the first evidence of Locke's commitment to the principle that minimalistic theism would suffice for peaceable coexistence in any civil society.

In April 1667, John Locke departed his lodgings in Christ Church, Oxford for the London household of Anthony Ashley Cooper, Lord Ashley. ${ }^{1}$ Although Locke's day-to-day activities are not precisely known, the writing of the earliest drafts of his Essay Concerning Toleration occurred during this period, specifically after the publication of Sir Charles Wolseley's Liberty of Conscience, the Magistrates Interest in the autumn of $1667 .^{2}$ The impetus for the Essay is a matter of debate. The fall of the Earl of Clarendon after the Dutch raid on the Medway (19-24

\footnotetext{
${ }^{1}$ For an overview of this period see J. R. Milton, “The Unscholastic Statesman: Locke and the Earl of Shaftesbury," in John Spurr, ed., Anthony Ashley Cooper, First Earl of Shaftesbury, 1621-1683 (Farnham, 2011), 153-81, at 153-60. The serial numbers in note 33 below refer to Donald Wing, Short-Title Catalogue of Books Printed in England, Scotland, Ireland, Wales, and British America, and of English Books Printed in Other Countries, 1641-1700, ed. John J. Morrison and Carolyn W. Nelson, 2nd edn (New York, 1982-94); the abbreviation ESTC in note 33 below refers to serial numbers in the English Short Title Catalogue (estc.bl.uk). Dates are New Style, unless otherwise noted.

${ }^{2}$ For the relationship between Locke's Essay and Wolseley's Liberty of Conscience see J. C. Walmsley and Felix Waldmann, "John Locke and the Toleration of Catholics: A New Manuscript," Historical Journal 62/4 (2019), 1093-1115.

(C) The Author(s), 2021. Published by Cambridge University Press. This is an Open Access article, distributed under the terms of the Creative Commons Attribution licence (http://creativecommons.org/licenses/by/4.0/), which permits unrestricted re-use, distribution, and reproduction in any medium, provided the original work is properly cited.
} 
June 1667) had spurred nonconformists to press for a new church settlement, reversing or ameliorating the persecutory regime that had taken hold since the Restoration, when Nonconformist worship was assailed by the successive passage of the Act of Uniformity (1662), the Conventicle Act (1664), and the Five Mile Act (1665). The possibility that Charles II would issue a bill for the "comprehension" or "indulgence" of Nonconformity-making his rule congenial to the sizeable corps of Dissenters it had previously discountenanced by comprehending their worship within the Church of England or indulging their worship outside itprompted a wave of publications on the justification or dangers of religious toleration. ${ }^{3}$ Locke's position on this matter had evolved markedly since 1660-62 and his Two Tracts on Government. The latter had defended the power of the magistrate to "impose and determine" aspects of worship-the wearing of the surplice, for example-that Dissenters had described as "adiaphora" or "things indifferent" to the question of salvation. ${ }^{4}$ The stringency of the Tracts stemmed, in part, from an evident fear of the return of seditious violence, which defenders of the Church of England had attributed to the rise of Nonconformity during the Civil Wars. Yet Locke's position subsequently altered, particularly after his exposure to the religious pluralism of Cleves in 1665-6, when he visited the duchy in the train of a diplomatic mission. ${ }^{5}$ By the following year, having commenced a draft of the Essay, Locke would move towards the rudiments of his Epistola de Tolerantia, in which the imposition of uniformity in matters of worship and "speculative belief" was criticized on several interdependent grounds: soteriological, epistemic, and political.

Locke's path to this position is the subject of considerable scholarship, lately enriched by the meticulous work of Jacqueline Rose and Jeffrey Collins. ${ }^{6}$ The textual milestones on this path-Locke's Two Tracts, his Reasons for Tolerateing Papists Equally with Others, and his Essay - are typically studied alongside a set of notes to A Discourse of Ecclesiastical Politie, a work of 1669 by the Church of England cleric and controversialist Samuel Parker (1640-88). The notes were purchased by the Bodleian Library from a private owner in 1954 and first published-in part-in Maurice Cranston's John Locke, A Biography (1957). ${ }^{7}$ Mark Goldie subsequently provided an abbreviated transcription of the notes in his edition of Locke's Political Essays (1997), after which J. R. Milton and Philip Milton included a fullscale transcription in their Clarendon edition of Locke's Essay Concerning

\footnotetext{
${ }^{3}$ For a summary of the debate see Roger Thomas, "Comprehension and Indulgence," in Geoffrey F. Nuttall and Owen Chadwick, eds., From Uniformity to Unity, 1662-1692 (London, 1962), 189-253; Paul Seaward, The Cavalier Parliament and the Reconstruction of the Old Regime, 1661-1667 (Cambridge, 1989), 162-95; John Coffey, Persecution and Toleration in Protestant England, 1558-1689 (Harlow, 2000), 166-79; John Locke, An Essay Concerning Toleration and Other Writings on Law and Politics, 1667-1683, ed. J. R. Milton and Philip Milton (Oxford, 2006), 152-7 (hereafter ECT).

${ }^{4}$ For this work see John Locke, Two Tracts on Government, ed. Philip Abrams (Cambridge, 1967).

${ }^{5}$ For this episode see Luisa Simonutti, "Political Society and Religious Liberty: Locke at Cleves and in Holland," British Journal for the History of Philosophy 14/3 (2006), 413-36.

'Jacqueline Rose, "John Locke, 'Matters Indifferent,' and the Restoration of the Church of England," Historical Journal 48/3 (2005), 601-21; Rose, "John Locke and the State of Toleration," Journal of Ecclesiastical History 64/1 (2013), 112-20; Jeffrey Collins, In the Shadow of Leviathan: John Locke and the Politics of Conscience (Cambridge, 2020).

${ }^{7}$ Maurice Cranston, John Locke, A Biography (London, 1957), 131-3.
} 
Toleration. ${ }^{8}$ The notes-particularly in those places in which Locke voiced a judgment of his own and departed from ad litteram transcription-appeared to be preparatory to a direct response to Parker's Discourse. But no such work was ever published and no further evidence of the project appeared to survive.

The Miltons were the first to observe that the notes on Parker appeared to be "stray survivors from a considerably fuller body of notes that have since been lost." The following article confirms the Miltons' judgment. In 2016, J. C. Walmsley discovered a set of notes in Locke's handwriting, which constitute at least part-and perhaps all-of the missing notes that the Miltons conjecturally described. The notes are now preserved in the University of North Carolina at Chapel Hill: a manuscript bifolium (now disjoined) of approximately three thousand words, with Locke's remarks and queries regarding the preface and first 158 pages of Parker's Discourse, presented under the headings "Magistrate" and "Church." The previously known Bodleian manuscripts comprise three bifolia, the first a paraphrase of pages 1-64 of the Discourse, the second a set of queries regarding pages 11-30, and the third a set of queries regarding pages 144-53. Until its discovery in 2016, the Chapel Hill manuscript was unknown to scholars: no publications refer to its existence and no catalogue advertising its sale can be found. The following article provides the first discussion and transcription of the manuscript. It begins by contextualizing Parker's Discourse (section I), before addressing the implications of the discovery for future studies of Locke's theory of toleration and his authorial and secretarial practices, c.1669-in particular, it draws attention to the principal significance of the manuscript, as the first evidence of Locke's commitment to the doctrine that minimalistic theism would suffice for peaceable coexistence in any civil society (section II). The article then turns to a reconstruction of the provenance, structure, and content of the manuscript (section III) and it concludes with a transcription of the manuscript, and a retranscription of its counterparts in the Bodleian (section IV). In providing this full-scale transcription, the article constitutes the first complete edition of Locke's extant commentary on Parker.

\section{I}

Parker was born in Northampton in September $1640 .{ }^{10}$ He entered Wadham College, Oxford in September $1656,{ }^{11}$ where he matriculated in October 1657, and graduated BA in February 1659. ${ }^{12}$ His reputation at this time was apparently

\footnotetext{
${ }^{8} E C T, 57-70,192-4,322-6$.

${ }^{9} E C T, 194$.

${ }^{10}$ For Parker's biography see Jon Parkin, "Parker, Samuel (1640-1688)," in H. C. G. Matthew and Brian Harrison, eds., Oxford Dictionary of National Biography, 60 vols. (Oxford, 2004), 42: 736-8; Jason Jewell, “Authority's Advocate: Samuel Parker, Religion, and Politics in Restoration England” (Ph.D. diss., Florida State University, 2004), 3-28.

${ }^{11}$ Bodleian Library, Wood MSS F 46, fo. 272r, Samuel Parker to Anthony Wood, 20 Aug. 1682.

${ }^{12}$ The date of Parker's graduation is the subject of confusion: Anthony Wood, Fasti Oxonienses or the Annals of the University of Oxford, in Wood, Athenae Oxonienses, ed. Philip Bliss, 5 vols. (London, 1813-20), 4: 218, records the date ("Feb. 28") without clarifying whether it is NS or OS in 1659/60; Joseph Foster, ed., Alumni Oxonienses 1500-1714, 4 vols. (Oxford, 1891-2), 3: 1116, records the date as "28 Feb., 1659-60," which is reproduced in John Venn and John A. Venn, eds., Alumni Cantabrigienses,
} 


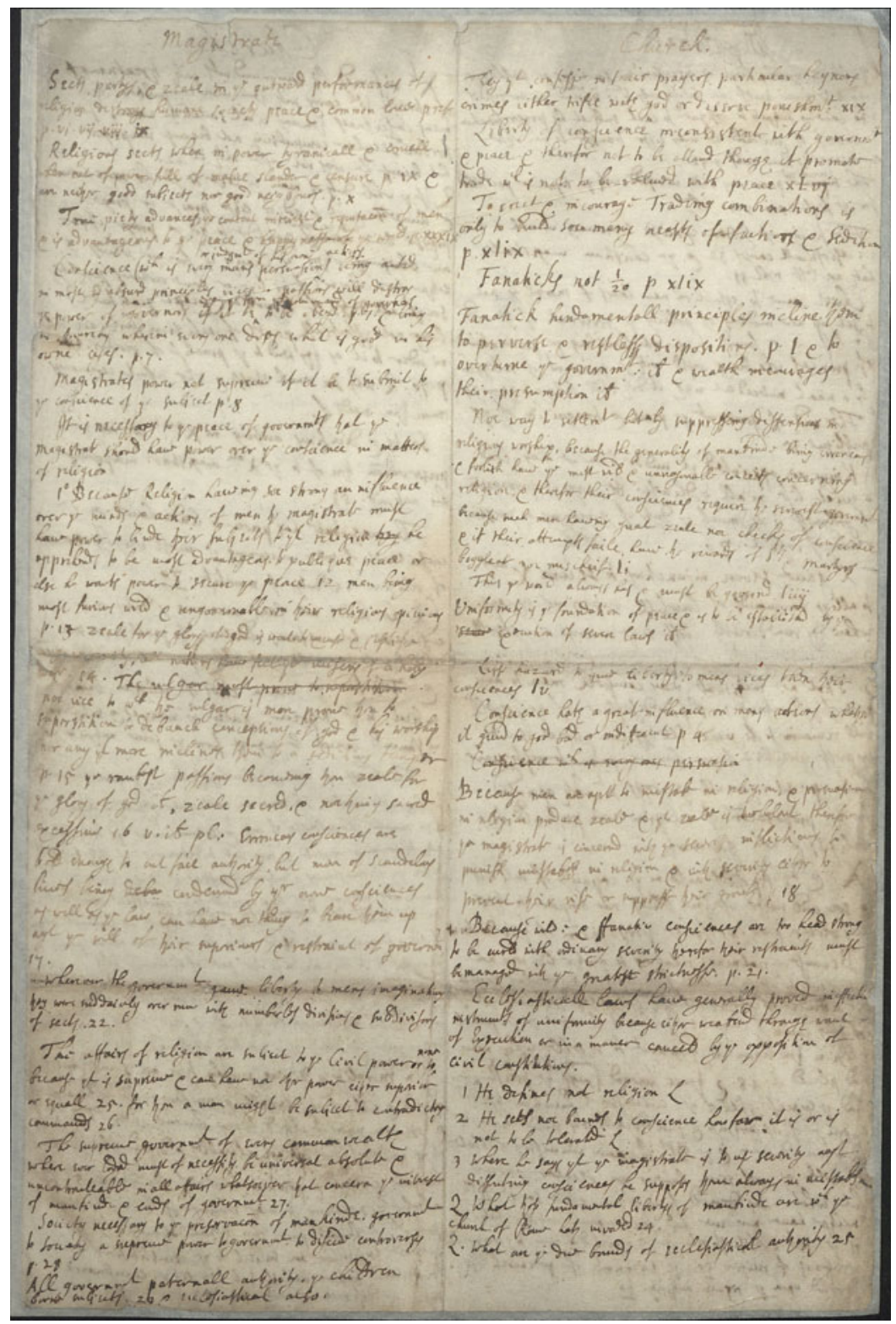

Fig. 1. University of North Carolina at Chapel Hill, Wilson Library, Southern Historical Collection, 03406 (Folder 323), fo. 1r.

as an ascetic puritan. According to his vita in Anthony Wood's Athenae Oxonienses (1691-2), Parker was "so zealous and constant a hearer of the prayers and sermons ... a receiver of the sacraments and such like, that he was esteemed one of the

pt. I, 4 vols. (Cambridge, 1922-7), 3: 308. The date in R. B. Gardiner, The Registers of Wadham College, Oxford, 2 vols. (London, 1889-95), 1: 221, and Parkin, "Parker," 42: 737, is "28 February 1659." 
preciousest young men in the university." ${ }^{13}$ A contretemps with the warden of Wadham, Walter Blandford (1615/16-75), impelled him to enter Trinity College, Oxford in October 1660, where he graduated MA in July $1663,{ }^{14}$ and began an association with Ralph Bathurst (1619/20-1704), a fellow of the college. ${ }^{15}$ Parker would later attribute to Bathurst's influence his "first Rescue from the Chains and Fetters of an unhappy Education."16 This eschewal of puritanism was followed swiftly by Parker's ordination in February $1665 .{ }^{17}$ In the same year, his Tentamina de Deo (1665) was dedicated to Gilbert Sheldon (1598-1677), the Archbishop of Canterbury. ${ }^{18}$ The Tentamina was reviewed positively by Henry Oldenburg (c.1619-77) in the first volume of the Philosophical Transactions of the Royal Society, ${ }^{19}$ and supplemented by two elucidations, A Free and Impartial Censure of the Platonick Philosophie (1666) and An Account of the Nature and Extent of the Divine Dominion and Goodnesse (1666), which were reissued in a conjoined second edition in $1667 .{ }^{20}$ These works had several preoccupations: positing a compatibility between the new natural philosophy and "scholastic theology," disinfesting Christianity of Platonism, defending the neurology of Thomas Willis $(1621-75),{ }^{21}$ and attacking the Origenist position on the preexistence of the soul and the work of its alleged revivalists Henry More (1614-87) and Joseph Glanvill (1636-80). ${ }^{22}$ With the nomination of John Wilkins (1614-72), Parker

\footnotetext{
${ }^{13}$ Wood, Athenae Oxonienses, 4: 226, printed in the first edition of Athenae Oxonienses, 2 vols. (London, 1691-2), 2: 616.

${ }^{14}$ Wood, Fasti, 266; Foster, Alumni Oxonienses, 3: 1116.

${ }^{15}$ For this phase in Parker's life see Thomas Warton, The Life and Literary Remains of Ralph Bathurst (London, 1761), 157-8.

${ }^{16}$ Samuel Parker, A Free and Impartial Censure of the Platonick Philosophie (Oxford, 1666), A3v; Wood, Athenae Oxonienses, 4: 226.

${ }^{17}$ For the year of his ordination see Clergy of the Church of England database (CCEd, at theclergydatabase.co.uk), ID 6683 (Feb. 1665); Lambeth Palace Library (LPL), Act Books of the Archbishops of Canterbury (AB), vol. 1, fo. 166r (Dec. 1665), Faculty Office (FO), Muniment Books (MB), F I/C, fo. $189 \mathrm{r}$ and Fiats, F II/6/71 (Dec. 1665), correcting ECT, 58, which presumably followed William Holden Hutton, "Parker, Samuel," in Leslie Stephen and Sidney Lee, eds., Dictionary of National Biography, 63 vols. (London, 1885-1900), 43: 272-5, at 272.

${ }^{18}$ Samuel Parker, Tentamina physico-theologica de Deo (London, 1665), a3r-a2v. For Parker's high estimation of Sheldon see Samuel Parker, De rebus sui temporis commentariorum (London, 1726), 27-8; and the copy annotated by Parker's son Samuel Parker (1681-1730), Bodleian Library, $4^{\circ}$ Rawl. 325.

${ }^{19}$ [Henry Oldenburg], "An Account of Some Books, Not Long Since Published," Philosophical Transactions 1/18 (1666), 324-5.

${ }^{20}$ For these works see Falconer Madan, Oxford Books, 3 vols. (Oxford, 1895-1931), 3: 210 (2754), 211 (2755), 218 (2779). For Oldenburg's commendation of Parker's Censure see Robert Boyle, The Correspondence of Robert Boyle: 1666-1667, ed. Michael Hunter, Antonio Clericuzio, and Lawrence M. Principe, 6 vols. (London, 2001), 3: 165-9.

${ }^{21}$ For Parker's interest in Willis see Louis Caron, "Thomas Willis, the Restoration and the First Works of Neurology," Medical History 59/4 (2015), 525-53, at 550-52; for Locke's interest in Willis see Thomas Willis, Thomas Willis's Oxford Lectures, ed. Kenneth Dewhurst (Oxford, 1980).

${ }^{22}$ For these works see Rhodri Lewis, "Of 'Origenian Platonisme': Joseph Glanvill on the Pre-existence of Souls," Huntington Library Quarterly 69/2 (2006), 267-300, at 285-7; Dmitri Levitin, "Rethinking English Physico-theology: Samuel Parker's Tentamina De Deo (1665)," Early Science and Medicine 19/1 (2014), 2875; Levitin, Ancient Wisdom in the Age of the New Science: Histories of Philosophy in England, c. 1640-1700 (Cambridge, 2015), 144-5, 496-8.
} 
was elected a fellow of the Royal Society in June $1666 .{ }^{23}$ In "Michaelmas 1667 "24 he was chosen to serve as Sheldon's domestic chaplain. In October he was made rector of Chartham in Kent and created MA by incorporation in Cambridge. ${ }^{25}$

In roughly November 1669, A Discourse of Ecclesiastical Politie was published in London, bearing "1670" as its date of publication. Parker's publisher John Martyn (c.1619-80) had entered the work with the Stationers' Company in September $1669 .^{26} \mathrm{~A}$ second edition-described as such in the term catalogues, but not the work itself-was issued in February $1670,{ }^{27}$ with minor corrections to the signatures and pagination, as well as the interpolation of the adjective "External" before the word "Religion" in the subtitle: Wherein The Authority of the Civil Magistrate Over the Consciences of Subjects in Matters of External Religion is Asserted. The Miltons describe Parker's work as a "belated" contribution to the debate of 1667-8 over the prospect of a bill of indulgence or comprehension. ${ }^{28}$ The titular allusion to Richard Hooker's Of the Lawes of Ecclesiastical Politie (1594-7) served to align its argument with the "the flagship text of late-Elizabethan conformity," 29 associating Hooker with a campaign that had-through Sheldon's officesorchestrated a barrage of rejoinders to tolerationists in the previous year. ${ }^{30} \mathrm{~A}$ third but substantively unaltered edition, anonymous like the first and second, was issued in November 1670, although dated "1671,"31 to coincide with the publication of a separate and still anonymous Defence and Continuation of the Ecclesiastical Politie (1671), ${ }^{32}$ in which Parker reiterated his initial case at greater

\footnotetext{
${ }^{23}$ For Parker's election see Michael Hunter, The Royal Society and Its Fellows 1660-1700: The Morphology of an Early Scientific Institution, 2nd edn (Oxford, 1994), 174. Parker was removed from the rolls of the Society after 1684 for nonpayment of dues. Hunter, The Royal Society, 198-9.

${ }^{24}$ For this date see Bodleian Library, Wood MSS F 46, fo. 272r; and Wood, Athenae Oxonienses, 4: 277. Parkin, "Parker," 42: 737, dates this to "November 1667," but the date presumably fell before Parker's appointment to the rectory of Chartham in October 1667 (note 25 below).

${ }^{25}$ LPL, AB, vol. 2, fo. 104r; and Vicar General, Diocesan Records (VG), 1/5, p. 18 (31 Oct. 1667); Venn and Venn, Alumni Cantabrigienses, 3: 308.

${ }^{26}$ G. E. B. Eyre and G. R. Rivington, eds., A Transcript of the Registers of the Worshipful Company of Stationers from 1640-1708, 3 vols. (London, 1913-14), 2: 405 (23 Sept. 1669); and Edward Arber, ed., The Term Catalogues, 1668-1709, 3 vols. (London, 1903-6), 1: 21 (22 Nov. 1669). Jon Parkin, "Hobbism in the Later 1660s: Daniel Scargill and Samuel Parker," Historical Journal 42/1 (1999), 85-108, at 97 n. 46 , describes the use of " 1670 " on the title page as an "error," but postdating by publishers was commonly practiced.

${ }^{27}$ Joseph Black, "The Unrecorded Second Edition of Samuel Parker's A Discourse of Ecclesiastical Polity," Notes and Queries 242 (1977), 187-9. Black omits to note that the second edition was advertised as such in Arber, The Term Catalogues, 1: 28 (17 Feb. 1670).

${ }^{28} E C T, 58$.

${ }^{29}$ Jacqueline Rose, “The Ecclesiastical Polity of Samuel Parker," Seventeenth Century 25/2 (2010), 350-75, at 359; Michael Brydon, The Evolving Reputation of Richard Hooker: An Examination of Responses, 16001714 (Oxford, 2006), 120.

${ }^{30}$ For Sheldon's coordination of this campaign see Walter G. Simon, "Comprehension in the Age of Charles II," Church History 31/4 (1962), 440-8, at 441, 444-5; Victor D. Sutch, Gilbert Sheldon: Architect of Anglican Survival, 1640-1675 (The Hague, 1973), 110-16.

${ }^{31}$ Arber, The Term Catalogues, 1: 62 (22 Nov. 1670).

${ }^{32}$ For the date of publication of Parker's Defence see Richard Baxter, Reliquiae Baxterianae, ed. N. H. Keeble, John Coffey, Tim Cooper, and Tom Charlton, 5 vols. (Oxford, 2020), 2: 376; Eyre and Rivington, A Transcript of the Registers of the Worshipful Company of Stationers, 2: 417 (24 Oct. 1670); Arber, The Term Catalogues, 1: 58 (22 Nov. 1670).
} 
length—the Discourse was 326 pages, the Defence was 750 pages—and responded to Truth and Innocence Vindicated ... A Survey of a Discourse Concerning Ecclesiastical Polity (1669), by John Owen (1616-83), the doyen of Congregationalism. ${ }^{33}$

Owen had initially asked Richard Baxter (1615-91) to respond to Parker. ${ }^{34}$ Baxter having declined, Owen completed the task himself, in a point-by-point confutation of the first six chapters of Parker's work. This was accompanied, in 1669, by A Case of Conscience ... Together with Animadversions on a New Book, Entituled, Ecclesiastical Polity by John Humfrey (c.1621-1719), the Nonconformist proponent of comprehension. The impetus for Owen's and Humfrey's interventions was, in part, Parker's unusually intemperate style. ${ }^{35}$ The Discourse teemed with aspersions about Nonconformists: "Brain-sick people," "Madmen," "vermin." ${ }^{36}$ Parker's subsequent preferment is often attributed to the depth of this commitment to "Sheldonianism." ${ }^{37}$ In May 1670 he was appointed archdeacon of Canterbury. ${ }^{38}$ In July 1671 he was preferred to the living of Ickham in Kent. ${ }^{39}$ In November 1671 he was awarded a DD and "perhaps D. Med." in Cambridge. ${ }^{40}$ In November 1672 he was admitted to a prebend in Canterbury. ${ }^{41}$ Five months earlier, in June, a posthumous work by John Bramhall (1594-1663) was entered in the term catalogues: Bishop Bramhall's Vindication of Himself and the Episcopal Clergy, from the Presbyterian Charge of Popery, as it is Managed by Mr. Baxter in his Treatise of the Grotian Religion (1672). ${ }^{42}$ Parker contrived to adjoin a separate treatise to Bramhall's critique of Baxter's Grotian Religion Discovered (1658), in which he renewed the Discourse's attack on Nonconformity. Baxter contemplated a response, ${ }^{43}$ but it was Andrew Marvell (1621-78), the parliamentarian and poet, who stridently intervened.

\footnotetext{
${ }^{33}$ Wing gives the serial number P459 to the first edition (= ESTC, R1397), P460 (= ESTC, R2071) to the third edition, and P457 (= ESTC, R22456) to the Defence. The second edition (= ESTC, R227228) is not recorded in Wing. Citations of the Discourse below refer to P459.

${ }^{34}$ Baxter, Reliquiae, 2: 376.

${ }^{35}$ For Parker's style see Raymond A. Anselment, "Betwixt Jest and Earnest": Marprelate, Milton, Marvell, Swift, and the Decorum of Religious Ridicule (Toronto, 1979), 94-125; John Spurr, "Style, Wit and Religion in Restoration England," in Stephen Taylor and Grant Tapsell, eds., The Nature of the English Revolution Revisited: Essays in Honour of John Morrill (Woodbridge, 2013), 233-60, at 244.

${ }^{36}$ Parker, Discourse, iv, 1.

${ }^{37}$ For this phrase see Martin Dzelzainis and Annabel Patterson, "Introduction: Rehearsal Transpros'd," in Andrew Marvell, The Prose Works of Andrew Marvell, ed. Martin Dzelzainis, Annabel Patterson, Nicholas von Maltzahn, and N.H. Keeble, 2 vols. (New Haven, 2003), 1: 3-40, at 7.

${ }^{38} \mathrm{LPL}, \mathrm{AB}$, vol. 3 , fo. 9 r and VG $1 / 5$, p. 34.

${ }^{39} \mathrm{LPL}, \mathrm{AB}$, vol. 3, fos. 92v, 93v; FO, MB, F I/D, fo. 34v; FO, Fiats, F II/12, fos. 90a-b; VG 1/5, p. 38.

${ }^{40}$ For this phrase see Foster, Alumni Oxonienses, 3: 1116; Venn and Venn, Alumni Cantabrigienses, 3: 308, notes elliptically that Parker was "[p]robably D. D. (Cambridge) 1671 (Lit [eras] Reg[ias])."

${ }^{41}$ The National Archives, Kew, SP 44/27, fo. 39r, F. H. Blackburne Daniell, ed., Calendar of State Papers Domestic: Charles II, 1672-3 (London, 1901), 73; LPL, AB, vol. 3, fo. 174r; VG 1/5, p. 44; Joyce M. Horn et al., eds., Fasti Ecclesiae Anglicanae 1541-1857, 12 vols. (London, 1969-86), 3: 15-21, 8: 75-80.

${ }^{42}$ Arber, The Term Catalogues, 1: 109 (24 June 1672); and Eyre and Rivington, A Transcript of the Registers of the Worshipful Company of Stationers, 2: 446 (7 Sept. 1672).

${ }^{43} \mathrm{~N}$. H. Keeble and Geoffrey F. Nuttall, eds., Calendar of the Correspondence of Richard Baxter, 2 vols. (Oxford, 1991), 2: 138 (895).
} 
In around April 1672, Marvell commenced work on The Rehearsal Transpros'd. ${ }^{44} \mathrm{He}$ completed it in September 1672; it was published in December, pirated twice, and swiftly followed by a second edition in around January $1673 .^{45}$ In response, Parker reprinted his preface to Bramhall's Vindication and completed A Reproof to the Rehearsal Transpros'd (c. May 1673), ${ }^{46}$ to which Marvell answered with a Second Part to his Rehearsal (November 1673), subjecting Parker to withering criticism, partly in the form of a derisive biography. ${ }^{47}$ The controversy soon widened. Henry Stubbe's Rosemary and Bayes (1672) attacked both Marvell and Parker. John Humfrey's The Authority of the Magistrate, about Religion (1672) and Robert Ferguson's A Sober Enquiry into the Nature, Measure, and Principle of Moral Virtue (1673) criticized Parker, without defending Marvell. Edmund Hickeringill's Gregory, Father-Greybeard (1673) defended Parker-and criticized Marvell sufficiently to warrant the latter's ridicule in the Second Part to his Rehearsal.

The debate made Parker synonymous with hierocratic intolerance. ${ }^{48}$ In 1673 , this notoriety was compounded by an embarrassing miscalculation, committed in Parker's role of licenser to the press, which he held ex officio as a chaplain to Sheldon. Parker had licensed Mr. Baxter Baptiz'd in Bloud; or, A Sad History of the Unparallel'd Cruelty of the Anabaptists in New England (1673), a work narrated as a truthful tale of the murder by Nonconformist sectarians of "Benjamin Baxter," a Church of England minister. ${ }^{49}$ In May 1673 the Privy Council investigated the work and found its claims to be entirely fictitious. ${ }^{50}$ Parker was compelled to acknowledge his error before the council ${ }^{51}$ as John Darby (d. 1704)-in all probability the printer of both parts of The Rehearsal Transpros'd-published an

\footnotetext{
${ }^{44}$ For Marvell's Rehearsal Transpros'd see Jon Parkin, "Liberty Transpros'd: Andrew Marvell and Samuel Parker," in Warren Chernaik and Martin Dzelzainis, eds., Marvell and Liberty (Basingstoke, 1999), 269-89; Derek Hirst, "Samuel Parker, Andrew Marvell, and Political Culture," in Derek Hirst and Richard Strier, eds., Writing and Political Engagement in Seventeenth-Century England (Cambridge, 1999), 145-64; Annabel Patterson and Martin Dzelzainis, "Marvell and the Earl of Anglesey: A Chapter in the History of Reading," Historical Journal 44/3 (2001), 703-26; Lana Cable, "Licensing Metaphor: Parker, Marvell, and the Debate over Conscience," in Jennifer Andersen and Elizabeth Sauer, eds., Books and Readers in Early Modern England (Philadelphia, PA, 2002), 243-60; Mark Goldie, "Marvell and His Adversaries, 1672-1678," in Martin Dzelzainis and Edward Holberton, eds., The Oxford Handbook of Andrew Marvell (Oxford, 2019), 703-21, at 714-21.

${ }^{45}$ Nicholas von Maltzahn, An Andrew Marvell Chronology (Basingstoke, 2005), 134-8. For these editions see Dzelzainis and Patterson, "Introduction," 32 n. 74; Andrew Marvell, The Rehearsal Transpros'd; and, The Rehearsal Transpros'd, the Second Part, ed. D. I. B. Smith (Oxford, 1971), xxv, xxvii-iii, xxx.

${ }^{46}$ British Library, Add. MS 70012, fos. 58r-9v; Andrew Marvell to Sir Edward Harley, 3 May 1673, printed (with errors) in Andrew Marvell, Poems and Letters, ed. H. M. Margoliouth, 3rd ed., rev. Pierre Legouis with the collaboration of E. E. Duncan-Jones, 2 vols. (Oxford, 1971), 2: 328-9 (22).

${ }^{47}$ Annabel Patterson, Marvell: The Writer in Public Life (London, 2000), 115-16.

${ }^{48}$ Wood, Athenae Oxonienses, 4: 231; Gilbert Burnet, Bishop Burnet's History of His Own Time, 6 vols. (Oxford, 1823), 1: 451.

${ }^{49}$ For the attribution of the work to Parker see Marvell, The Prose Works, 1: 279.

${ }^{50}$ The National Archives, Kew, SP 29/335, pt. 2, fo. 158r (235), abstracted in F. H. Blackburne Daniell, ed., Calendar of State Papers Domestic: Charles II, 1673 (London, 1902), 312 (30 May 1673); W. D. Christie, ed., Letters Addressed from London to Sir Joseph Williamson, 2 vols. (London, 1874), 1: 28 (no. 14).

${ }^{51}$ The National Archives, Kew, PC 2/64, p. 30; Bodleian Library, MS Tanner 290, fo. 202r; [John Darby?], Forgery Detected and Innocency Vindicated (London, 1673), 12-13.
} 
account of the affair. ${ }^{52}$ Notwithstanding his appointment in August 1673 as master of the Hospital of Eastbridge in Canterbury, Parker's rise stuttered to a halt. ${ }^{53}$ In 1673, he seems to have withdrawn from London to Kent, where he remained until 1684. ${ }^{54}$ He declined to publish again until 1678, when he issued his Disputationes de Deo et Providentia Divina. The death of Sheldon in November $1677,{ }^{55}$ followed by the appointment of Parker's rival William Sancroft (1617-93) to the archbishopric of Canterbury, ended Parker's hopes for promotion to a bishopric-although only temporarily. ${ }^{56}$

In the 1680s, Parker continued to write on matters of theology. A Demonstration of the Divine Authority of the Law of Nature and of the Christian Religion (1681) was joined by The Case of the Church of England Briefly and Truly Stated (1681), An Account of the Government of the Christian Church (1683) and In Religion and Loyalty (1684-5), arguing variously for the necessity of absolute obedience to a temporal sovereign and iure divino episcopacy. The accession of James II changed Parker's fortunes practically overnight. ${ }^{57}$ In July-August 1686 James nominated Parker to succeed John Fell (1625-86) as Bishop of Oxford. ${ }^{58}$ In the following year, Parker endorsed James's Declaration of Indulgence. ${ }^{59}$ In August 1687 he was nominated president of Magdalen College, Oxford, designedly to pressure the fellowship into admitting Roman Catholics. ${ }^{60}$ A purge of twenty-five fellows in November was followed, in the next month, by the publication of Parker's Reasons for Abrogating the Test (1687), which questioned the Church of England's stance on transubstantiation. ${ }^{61}$ Parker's subsequent presidency was characterized by suspicion of his crypto-Catholicism, but it was cut short by illness. He died in March 1688 and he was buried in Magdalen's chapel, without a memorial. His self-authored and tendentious Latin epitaph is reported by Wood:

\footnotetext{
${ }^{52} E C T, 60$, which erroneously describes Darby as Marvell's "publisher."

${ }^{53}$ LPL, VG 1/5, p. 47; AB, vol. 3, fo. 201r; Edward Hasted, The History and Topographical Survey of the County of Kent, 2nd edn, 12 vols. (Canterbury, 1797-1801), 12: 115-35.

${ }^{54}$ For evidence of Parker's withdrawal see LPL, MS 639, fos. 163r-70v.

${ }^{55} E C T, 60$, erroneously dates Sheldon's death to "1676."

${ }^{56}$ For Parker's relationship with Sancroft see Jewell, “Authority's Advocate," 21-8; LPL, MS 674, fos. 57r60v, Parker to John Spencer, 26 April, 25 Aug., 14 Sept. 1686; Bodleian Library, MS Tanner MS 31, fos. 166r-175v, MS Cherry MS 23, fo. 321r, Parker to Henry Dodwell, 10 Dec. 1680; W. Singer, ed., The Correspondence of Henry Hyde, Earl of Clarendon, 2 vols. (London, 1828), 1: 150-1 (no. CXIX).

${ }^{57}$ For Parker's return to London in 1684 see Bodleian Library, MS Tanner 32, fol. 26r, Parker to Ralph Snowe, 16 April 1684; The National Archives, Kew, SP 44/335, pp. 222, 366, SP 44/57, p. 96, abstracted in F. H. Blackburne Daniell and Francis Bickley, eds., Calendar of State Papers, Domestic: Charles II, 1684-5 (London, 1938), 195, 207, 236.

${ }^{58}$ For Parker's appointment see LPL, FO, Fiats, F II/27, fos. 65a-b; Bodleian Library, Tanner MS 147, fo. 66r; The National Archives, Kew, SP 44/57, pp. 135, 140, abstracted in E. K. Timings, ed., Calendar of State Papers, Domestic: James II, 1686-7 (London, 1964), 273, 288.

${ }^{59}$ Jewell, “Authority's Advocate," 198; Bodleian Library, Rawl. D 843, fol. 113r.

${ }^{60}$ Laurence Brockliss, "The 'Intruded' President and Fellows," in Laurence Brockliss, Gerald Harriss, and Angus Macintyre, eds., Magdalen College and the Crown: Essays for the Tercentenary of the Restoration of the College, 1688 (Oxford, 1988), 83-106.

${ }^{61}$ [Samuel Parker], Reasons for Abrogating the Test, Imposed Upon all Members of Parliament Anno 1678 (London, 1688), 9-69.
} 
Omnes simultates et privatas inimicitias, non modo non fovi sed contempsi, sola integritate fretus.
All hatreds and private enmities, not only did I not foster, but I abhorred; trusting only in my integrity. $^{62}$

\section{II}

There is no evidence that Locke and Parker ever met, either during the period when they overlapped in Oxford (c.1656-c.1664) or at any subsequent time, prior to Parker's death, when Locke resided in England (1664-75, 1679-83). There are no extant letters between Locke and Parker, and there is no evidence that they ever exchanged letters. A letter of August 1687 from James Tyrrell (1642-1719) to Locke, then an exile in the Netherlands, refers to Parker as "our old Friend Dr: P.," ${ }^{\prime 63}$ but the intimation is sarcastic. Parker's name occurs on only three further occasions in Locke's correspondence: in a letter from Tyrrell of November 1687, referring to Parker's intrusion as president of Magdalen, ${ }^{64}$ in a letter from Tyrrell of July 1690, briskly complimenting Parker's Demonstration ... of the Law of Nature, ${ }^{65}$ and in a letter from Benjamin Furly (1636-1714), recalling that he and Locke had "read together" a satire on Parker's Reasons for Abrogating the Test. ${ }^{66}$ Locke's booklists record a copy Gilbert Burnet's eight-page critique (1688) of Parker's Reasons for Abrogating the Test, and a copy of Parker's Reproof to Marvell's Rehearsal Transpros'd. ${ }^{67}$ Locke possessed two copies of the First Part of Marvell's work-the pirated imprint of the first edition and bona fide second edition-and one copy of its Second Part, ${ }^{68}$ a copy of an anonymous contribution to the Parker-Marvell controversy, ${ }^{69}$ and a copy of Hickeringill's Gregory, Father-Greybeard. ${ }^{70}$

Martin Dzelzainis and Annabel Patterson have contended that Marvell, in his search for exempla of "disreputable conduct by figures in the past who could be seen as analogies for Parker," ${ }^{71}$ made use of Locke's personal library while writing

\footnotetext{
${ }^{62}$ Wood, Athenae Oxonienses, 4: 872. For parodic epitaphs of Parker see Thomas Hearne, Remarks and Collections of Thomas Hearne, ed. C. E. Doble, D. W. Rannie and H. E. Salter, 11 vols. (Oxford, 1885-1921), 2: 258; Beinecke Rare Book and Manuscript Library, Yale University, Osborn MS b209; British Library, Add. MS 21092, fo. 23r; Bodleian Library, MS Don. C. 55, fos. 13v-33v.

${ }^{63}$ E. S. de Beer, ed., The Correspondence of John Locke, 8 vols. to date (Oxford, 1976-) (hereafter CJL), 3: 257 (957).

${ }^{64}$ Ibid., 3: 288 (no. 973).

${ }^{65}$ Ibid., 4: 109 (no. 1307).

${ }^{66}$ Ibid., 4: 172 (no. 1344). De Beer identifies the satire tentatively as [John Phillips], Sam Ld. Bp. of Oxon. His Celebrated Reasons for Abrogating the Test and Notions of Idolatry Answered by Samuel, Archdeacon of Canterbury (London, 1688).

${ }^{67}$ John Harrison and Peter Laslett, eds., The Library of John Locke, 2nd edn (Oxford, 1971) (hereafter LJL), 203 (nos. 2199-2200).

${ }^{68}$ Ibid., 185-6 (nos. 1931-3); and Bodleian Library, Locke 7.256 (= LJL, no. 1932), 7.95 (= LJL, no. 1933). Locke's copy of the Second Part (7.95) has allusive-and, in the context of Locke's bindings, uncharacteristic-lettering on the spine ("Bayes Part II"), referring to the moniker assigned to Parker by Marvell, an allusion to the porte parole of Drydenic stagecraft in Marvell's parodic foil, The Rehearsal (1672) by George Villiers (1628-87), second Duke of Buckingham.

${ }^{69} L J L, 241$ (no. 2792).

${ }^{70}$ Ibid., 154 (no. 1447); and Bodleian Library, Locke 7.262 (= LJL, no. 1447).

${ }^{71}$ Patterson and Dzelzainis, "Marvell," 704.
} 
the First and Second parts of his Rehearsal Transpros'd. As an impecunious parliamentarian, deprived of the money to purchase books by the prorogation of Parliament between April 1671 and February 1673, Marvell appears to have relied on the library of his patron, Arthur Annesley (1614-86), the first Earl of Anglesey. The latter's vast collection of books contained all of the titles cited by Marvell in the Rehearsal Transpros'd, save for six works in specific editions that happen to be present in Locke's booklists: Sir William Davenant's Gondibert $(1651),{ }^{72}$ Samuel Butler's Hudibras (1663-4), ${ }^{73}$ Hickeringill's Gregory, Father-Greybeard, Richard Hooker's Of the Lawes of Ecclesiastical Politie (1666), Martin Del Rio's Disquisitionum magicarum (1600), ${ }^{74}$ and Ammianus Marcellinus' Rerum gestarum (1609). ${ }^{75}$ The difficulty with this claim is that, excepting the 1666 edition of Hooker, which Locke never owned, ${ }^{76}$ and a copy of Gondibert, which he demonstrably kept in his rooms in Christ Church in July $1681,{ }^{77}$ we cannot establish when Locke acquired each title, and thus whether they were accessible to Marvell in 1671-3. Marginal dashes and a page list in Locke's copy of Hickeringill suggest that Locke read the work, but this has no bearing on when he acquired it. ${ }^{78}$ Locke's copies of Butler, Del Rio, and Ammianus show no signs of consultation by Marvell, although one should note the intriguing presence of a versified Latin translation in Locke's hand on the flyleaf of his copy of Hudibras, which one might-outlandishly -attribute to Marvell's poetical influence. ${ }^{79}$ Locke's opinion of Marvell's Rehearsal is unknown-his copies do not bear any annotations and he does not refer to Marvell's work in any extant manuscript or publication-and no evidence survives to show that he ever met Marvell, yet an observer as informed as Roger L'Estrange (1616-1704) could wager in 1681 that Marvell was "very particularly acquainted" with the author of a Letter from a Parliament man to his Friend, Concerning the Proceedings of the House of Commons (1675), a pamphlet that probably issued from Shaftesbury's circle. ${ }^{80}$

\footnotetext{
${ }^{72} L J L, 120$ (no. 924a).

${ }^{73}$ Ibid., 159 (no. 1530); and New York, Columbia University, Health Sciences Library, PR3338.A71 1663 $(=L J L$, no. 1530).

${ }^{74} L J L, 122$ (no. 943); and Bodleian Library, Locke 7.293-5 (= LJL, no. 943).

${ }^{75}$ LJL, 183 (no. 1896); and Bodleian Library, Locke 9.63 (= LJL, no. 1896).

${ }^{76}$ For Locke's ownership of works by Hooker see Felix Waldmann, "The Library of John Locke: Additions, Corrigenda, and a Conspectus of Pressmarks," Bodleian Library Record 26 (2013), 36-58, at 47.

${ }^{77}$ Bodleian Library, MS Locke f. 5, p. 99; and $L J L, 274$.

${ }^{78}$ Gregory, Father-Greybeard was listed in the term catalogues on 16 June 1673 (Arber, ed., The Term Catalogues, 1: 142). Locke 7.262 has a page list ("p. 80, 104, 114") and marginal dashes on pages 80, 99, 104, 106, 107, 114. Marvell's references to Hickeringill in the Second Part of The Rehearsal Transpros'd do not match these annotations, save for page 104: Marvell, The Prose Works, 1: 226, 231, 233, 251-3, 284-6, 354, 385.

${ }^{79}$ For these verses see John Locke, Literary and Historical Writings, ed. J. R. Milton (Oxford, 2019), 12, which attributes the verses to John Harmar (c.1593-1670), on the basis of the attribution in Samuel Butler, Hudibras. The First Part (London, 1704), a7v-8r. The verses translate canto I, 11. 281-6, and canto III, 11. 773-6. Locke's version of III, 11. 773-6, and contemporary copies of the lines in Beinecke Rare Book and Manuscript Library, Yale University, Osborn MS fb66, item 32, fo.1r and Bodleian Library, MS Don. e. 6, fos. 37r-41v, differ from Harmar's and each other; it is possible that Locke translated III, 1l. 773-6, himself.

${ }^{80}$ [Roger L'Estrange], An Account of the Growth of Knavery, Under the Pretended Fears of Arbitrary Government (London, 1678), 5; John Marshall, John Locke: Resistance, Religion and Responsibility (Cambridge, 1994), 88. For Locke's use of a phrase ("so comfortable an importance") supposedly
} 
Notwithstanding the possibility of his collaboration with Marvell, Locke's interest in Parker is recoverable only from his notes to the latter's Discourse. Locke bought a copy of Parker's work soon after the publication of the first edition. A record of the purchase in his memorandum book for 1669 ("Parkers disc. - 0-3 〈shillings $\rangle-6$ (pence〉") occurs between entries on 15 November and 2 December, ${ }^{81}$ which one might safely conjecture delimits the period during which he acquired Parker's work. ${ }^{82}$ If the record of purchase is a terminus a quo in dating his notes to the Discourse, a terminus ad quem is provided by the endorsement he supplied to a portion of the notes: "69." This is a notation that Locke would have used until 25 March 1670, ${ }^{83}$ although it is possible that Locke might have emended his notes after that date without recording the day or year of the emendation. Locke's notes match only the pagination of the first edition, which could provide an additional temporal delimitation: if the second or third edition were available, Locke might have used it. The absence of the Discourse from Locke's booklistsor any extant copy that can be identified as Locke's own, or any references within the notes to other publications-complicates the task of establishing when Locke desisted in commenting on the work, which is only compounded by the mystery surrounding Locke's activities as a factotum in Ashley's household, c.1667-9.

Locke's intentions in writing his Essay Concerning Toleration remain obscure. The recent recovery of his Reasons for Tolerateing Papists Equally with Others has clarified the matter slightly, ${ }^{84}$ but it is difficult to favour one of several possibilities in explaining the Essay's aims. The Reasons and the Essay might have originated in Ashley's instruction to formulate a rationale for an indulgence of Nonconformists, or even Catholics, in anticipation of Charles II's or the Cabal ministry's designs after the fall of Clarendon. Yet Ashley's inclinations are difficult unambiguously to reconstruct between the aborted Declaration of Indulgence of 1662 and the Treaty of Dover of 1670 . The Miltons are thus rightly cautious of attributing the Essay to Ashley's direction, as "no evidence whatever has survived" of it. ${ }^{85}$ The intended audience for the Essay is similarly ambiguous: its use of the second person is too informal to suggest Charles II as a reader, at least. ${ }^{86}$ It is clear that Locke-whether independently of Ashley's purposes, in anticipation of them, or by Ashley's direction-had begun to familiarize himself with arguments in favor of the toleration of Nonconformists in late 1667, when Wolseley's Liberty of Conscience was published. The latter was issued by a coalition of printers and writers surrounding the Earl of Anglesey, including Marvell's publisher Nathaniel Ponder (1640-99) and John Darby. ${ }^{87}$ But the evidence of Locke's connection to the group is tenuous before March 1670, when the "longstanding

popularized by Marvell's work see CJL, 1: 503 n. 9, 506 (nos. 347-8). Marvell's nephew, William Popple (1638-1708), would later translate Locke's Epistola de Tolerantia.

${ }^{81}$ British Library, Add. MS 46470, fo. 40r.

${ }^{82}$ For a caveat about the dating of Locke's memoranda see J. R. Milton, "The Date and Significance of Two of Locke's Early Manuscripts," Locke Newsletter 19 (1988), 47-89, at 49-51.

${ }^{83}$ For an example of Locke dating the new year from 25 March see CJL, 1: 263-4 (no. 187).

${ }^{84}$ For this manuscript see Walmsley and Waldmann, "John Locke and the Toleration of Catholics."

${ }^{85} E C T, 49$.

${ }^{86}$ Ibid., 49.

${ }^{87}$ Walmsley and Waldmann, "John Locke and the Toleration of Catholics," 1101. 
enmity" that had characterized Anglesey's relationship with Ashley was briefly set aside after the renewal of the Conventicle Act by the Cavalier Parliament. ${ }^{88}$ Ashley dined with Anglesey on several occasions in $1671-2,{ }^{89}$ and he protected Ponder in January 1673 when the latter was censured for publishing the First part of Marvell's Rehearsal Transpros'd. ${ }^{90}$ It is not hard to imagine Ashley encouraging Locke in a similar enterprise, shortly after the publication of the Discourse. One of the three extant library catalogues of Ashley's grandson, the third Earl of Shaftesbury (1671-1713), records a copy of the Discourse, and one could plausibly assume that it was the copy used by Locke in preparing his notes on Parker's work. ${ }^{91}$ This is not to endorse the contention, pace Dzelzainis and Patterson, that the notes reveal Locke "bringing his views closer to [Ashley's]." 92 This begs the question. After all, what were Ashley's views? More objectionably, it severs the threads of continuity in emphasis and argumentation between the notes and Locke's Essay Concerning Toleration.

The notes reveal Locke's minute attention to Parker's reasoning. In the Chapel Hill manuscript, more so than in the Bodleian manuscripts, Locke engages in extensive transcription of Parker's wording, studded with queries marked "Q" for "Quaere" and signed "JL" or "L." The format of the notes is discussed below, but it is important to note the manner in which the notes move from excerpting the text under review to formulating a pointed response or reflection. The effect is similar in the Reasons, in which Locke used Wolseley's arguments as a foil to consider whether the toleration of Nonconformists would inadvertently favor Catholics or whether the toleration of Catholics might find its rationale in the "interest" or prosperity it entrained. Locke's Essay would echo Wolseley on this point, in buttressing a case for toleration by referring to its promotion of domestic "riches," 93 and it is not implausible to associate Locke's interest in Parker with an anxiety about the latter's criticism of the court's warmth for Wolseley's politique reasoning, as Collins has recently argued. ${ }^{94}$ In Collins's judgment, Parker jolted Locke out of his sympathy for Wolseley's position, and towards the elaboration of a clearer defence of freedom of speculative belief, detachable from any consideration of the magistrate's

\footnotetext{
${ }^{88}$ Douglas G. Greene, “Arthur Annesley, First Earl of Anglesey, 1614-1686” (Ph.D. thesis, University of Chicago, 1972), 82.

${ }^{89}$ British Library, Add. MS 40860, fo. 39v, partly printed in Historical Manuscripts Commission, Thirteenth Report, Appendix, Part VI: The Manuscripts of Sir William Fitzherbert, Bart., and Others (London, 1893), 263-5.

${ }^{90}$ For Shaftesbury's and Anglesey's protection of Ponder see Leicestershire Record Office, Finch Manuscripts, DG7, 4984, IX, p. 9/2, Historical Manuscripts Commission, Report on the Manuscripts of the late Allan George Finch, Esq., 4 vols. (London, 1913-65), 2: 10; and Patterson and Dzelzainis, "Marvell," 708-9.

${ }^{91}$ The National Archives, Kew, PRO 30/24/23/12, Catalogus Librorum Anglicorum, Gallicorum, Italicorum, \&c. utriusque Bibliotheca vizt. Aegidiana, \& Chelseyana Comitis de Shaftesbury. Aegidiis Anno Aerae Christianae 1709, fo. 59r, "S PARKER of Ecclesiastical Politie and Toleration. London 1670," without specifying an edition. The copy is absent from the present earl's collection in Wimborne St Giles and it is not advertised in the three Christie's catalogues (2-4 Nov. 1966, 8 Dec. 1966, and 14 Feb. 1967) that record the only public sales of the collection in Wimborne.

${ }^{92}$ Patterson and Dzelzainis, "Marvell," 720.

${ }^{93}$ For this argument see ECT, 289-90, 301.

${ }^{94}$ Collins, In the Shadow of Leviathan, 155, 162.
} 
"interest." But this difficulty constitutes only one portion of Locke's transcriptions and queries, which touch on several components of Parker's argument.

The earliest scholarship on the latter had tended misleadingly to characterize it as "Hobbism pure and simple." 95 Parker's language, stretching back to a laudatory citation of De Cive in Of the Nature and Extent of God's Dominion (1666), ${ }^{96}$ had drawn on Hobbes's metaphors, to the extent that Parker himself admitted his Discourse had "savour[ed] not a little of the Leviathan." 97 It is now generally accepted, however, that the resemblance of Parker's ecclesiology to Hobbes's in Leviathan is "overstated," 98 or arose merely from the latter's conceptual and rhetorical "proximity" to the Erastianism countenanced by Anglican royalists after 1660. ${ }^{99}$ Parker never accepted Hobbes's hyper-Erastian empowerment of the civil sovereign to dictate the theology of the established church. Perhaps more importantly, he never endorsed iure humano episcopacy, which he later decried in criticisms of Edward Stillingfleet's Irenicum (1659) and Mischief of Separation (1680). ${ }^{100}$ The irony of Parker's intentions, supposedly to associate Wolseley's "interest"-centered tolerationism with the chimera of a state grounded exhaustively in the areligious self-interest of its inhabitants, or Hobbesianism simpliciter, ${ }^{101}$ was that it was countervailed by a defence of temporal sovereignty so full-throated that it was-in Locke's judgment-indistinguishable from "Mr Hobbs's doctrine."102 The accusation was characteristic of the contemporary association of magisterial intervention in religious worship with "Hobbism" pur sang, and it betokened the flexible and polemical properties of that label. But the accusation stuck insistently to Parker for the remainder of his life. In March 1685 Henry Dodwell (1641-1711) could assure a correspondent that his friend's Discourse was not congenial to Hobbes, in spite of appearances. ${ }^{103}$

Parker used the Discourse to defend the royal prerogative in "Ecclesiastical Jurisdiction," while insisting that it ought not to be exercised by Charles II in favour of Nonconformity: Charles's principal obligation was to preserve the peace of his subjects, which was securable only via uniformity in outward religious practices. Freedom of "conscience," in Rose's summary of Parker's reasoning, "was a freedom

\footnotetext{
${ }^{95}$ A. A. Seaton, The Theory of Toleration under the Later Stuarts (Cambridge, 1911), 159. For echoes of this tendency see Gordon Schochet, "Between Lambeth and Leviathan: Samuel Parker on the Church of England and Political Order," in Nicholas Phillipson and Quentin Skinner, eds., Political Discourse in Early Modern Britain (Cambridge, 1993), 189-208; Gordon Schochet, "Samuel Parker, Religious Diversity, and the Ideology of Persecution," in Roger D. Lund, ed., The Margins of Orthodoxy: Heterodox Writing and Cultural Response, 1660-1750 (Cambridge, 1995), 119-48.

${ }^{96}$ Samuel Parker, An Account of the Nature and Extent of the Divine Dominion and Goodnesse (Oxford, 1666), 2.

${ }^{97}$ [Samuel Parker], A Defence and Continuation of the Ecclesiastical Politie (London, 1671), 279.

${ }^{98}$ Collins, In the Shadow of Leviathan, 155.

${ }^{99}$ Rose, "The Ecclesiastical Polity of Samuel Parker," 351.

${ }^{100}$ Bodleian Library, MS Tanner 36, fos. 255r-6v, Parker to Simon Patrick, [1681-2]; Bodleian Library, MS Eng. lett. c. 28, fos. 3v-4r, Parker to Henry Dodwell, 13 Nov. 1680; Richard Billinge, "Nature, Grace and Religious Liberty in Restoration England" (unpublished D.Phil. thesis, University of Oxford, 2015), 253-5.

${ }^{101}$ Jon Parkin, Taming the Leviathan: The Reception of the Political and Religious Ideas of Thomas Hobbes in England 1640-1700 (Cambridge, 2007), 255.

${ }^{102} \mathrm{O}_{3}$, "p. 144," fo. 9r. For this siglum and the convention of citing the manuscripts see section III below.

${ }^{103}$ Bodleian Library, MS St Edmund Hall 15, fo. 34v, Dodwell to Friedrich Spanheim, 11 March 1685.
} 
of judgement, not a freedom of action in worship." ${ }^{104}$ This was the significance of Parker's interpolation of External in the title page of the second edition. $\mathrm{He}$ reserved to the magistrate a power to impose "outward Practices" in religious worship. These "publique and visible" practices were controllable by civil authority, nourishing the allegation of Parker's sympathy for Hobbes's vision of a sacerdotal magistrate. But conscience, Parker maintained, was nonetheless inviolable.

These arguments plainly offended the principles that Locke had adumbrated in the manuscripts of his Essay Concerning Toleration in 1667-8. Parker permitted freedom of speculative belief, but insisted on outward conformity. The Essay had claimed that imposition in matters of conscience lay outside the competence of the magistrate, and this argument applied equally to imposition in matters of worship. Parker's attempt to disassociate freedom of conscience from freedom of external worship was an ingenious response to this proposition, but it could hardly persuade Locke that compulsion of external worship was compatible with the inviolable status of one's conscience. Locke's difficulty lay partly in how he could explain why this was specious, but a more urgent problem stemmed from his claim that religious sects were persecutable if their beliefs or their worship impinged upon civil matters. Catholics were excepted from toleration precisely because their theology required a commitment to the universal sovereignty of the Pope. If Catholicism was intolerable on this basis then so too was any religious sect whose doctrines carried deleterious implications for civil peace. Yet this was the nub of Parker's indictment of Nonconformity, and its force is obvious when one peruses Locke's commentary on the Discourse.

The Chapel Hill manuscript, in particular, focuses on Parker's insistence that unchecked Nonconformity would revive the antinomian political theology of the Civil Wars. Parker's "ecclesiastical politie" is invested with the necessary power to ensure the safety of its subjects. In the Chapel Hill manuscript, Locke concentrates on the scope of this power. "He sets noe bounds to conscience how far it is or is not to be tolerated," Locke notes, before asking, "What are the due bounds of ecclesiastical authority?" 105 Is anything, in matters of conscience, invulnerable to the oversight of the magistrate or the established church? Parker inveighs against the invasion by the Catholic Church of the "Fundamental Liberties of mankind." But "[w] hat," Locke asks, "[are] those fundamental libertys of mankinde ... which the church of Rome hath invaded?" 107 Locke adverts to the inconsistency in Parker's reasoning: Rome is contemptible because it invades precisely the liberties that the Discourse denies to Nonconformists.

The notes turn to Parker's emphasis on outward conformity. The dictates of conscience are not matters that can concern the magistrate until they issue in external actions. Only "outward Actions," Parker argues, are "subject to the Cognizance of Humane Laws." 108 "Opinions"- "moral or religious"-are outside the magistrate's cognizance until they are instantiated by action. But "are [opinions] not

\footnotetext{
${ }^{104}$ Rose, "The Ecclesiastical Polity of Samuel Parker," 359.

${ }^{105}$ C, "Church," "25," fo. 1 r.

${ }^{106}$ Parker, Discourse, 24.

${ }^{107}$ C, "Church," “24," fo. 1r.

${ }^{108}$ Parker, Discourse, 90.
} 
capable of haveing any influence upon the Publique good or ill of man kinde?" Locke asks. ${ }^{109}$ If the measure of a magistrate's authority is the preservation of civil peace, the latter would require the invigilation of "opinions." Parker insists that inward judgment is "inviolate." ${ }^{\text {"10 }}$ If its protection against civil compulsion is assured, "it matters not ... what restraints are laid upon our Outward Actions." 111 But this can only be true if our outward actions do not violate the dictates of our conscience: "whether ... [this] be true in any thing but barely what I judg in its self indifferent," Locke notes, "but what becomes of those things I judg unlawfull"? ${ }^{112}$ Parker alternates between treating the debate as one pertaining restrictedly to "ceremonies," which could be said to encompass only adiaphora, and one pertaining capaciously to "religion," which must encompass one's speculative beliefs, including in matters that are not "indifferent." Which is it? Locke demands. "Whether haveing in the foregoing $\$ \$ s \&$ this spoken only of ceremonys he doth not here call ceremonys religion"? "113 Locke quotes Parker in noting that the "dutys" of religious devotion are not "essentiall parts of religion." "Devotion" is performed only and superfluously because it tends "to the practise of vertue." "114 Following Parker's own logic, imposition in matters of "ceremony" must be dispensable to the "essentiall" object of religious belief, making any insistence on imposition in external worship rather similar to the politique position that Parker ostensibly eschews.

This precedes the most remarkable statement in the Chapel Hill manuscript. Parker observes that "Religion ... is the strongest Bond of Laws, and only support of Government." "[W]hen the Obligations of Conscience and Religion are Cashier'd, men can have no higher Inducements to Loyalty and Obedience, than the Considerations of their own Private interest and Security." 115 Parker, however, neglects to define "religion," yet again. Is it outward conformity, in our performance of mandatory ceremonies, or inward belief, in our assent to an article of faith? After summarizing Parker's position on religious belief as a source of "obligation to obedience," preferable simply to "self interest," Locke asks whether "religion" should extend "any farther then a beleife of god in general. but not of this particular worship." ${ }^{116}$ Belief in God "in general"- detached from any ceremonial or doctrinal appurtenances-is sufficient to ensure the moral conduct of a political subject. Parker's insistence on particular ceremonies in religion- "why soe much stress \& stir about ceremonys," 117 Locke asks-distracts from the possibility of civil coexistence on the basis of mere theism. It is clear that Locke arrived at this position after carefully considering Parker's reasoning. The compositional layers of the manuscript show that he returned to Parker's point on our "obligation to

\footnotetext{
${ }^{109}$ C, "Magistrate," “89," fo. 2 r.

${ }^{110}$ Parker, Discourse, 95.

${ }^{111}$ Ibid., 95.

${ }^{112}$ C, "Magistrate," "95," fo. 2 r.

${ }^{113}$ C, "Magistrate," “104," fo. 2 r.

${ }^{114}$ C, “Church,” “p. 70,” fo. 1v.

${ }^{115}$ Parker, Discourse, 141.

${ }^{116}$ C, "Magistrate," "140," fo. 2 r.

${ }^{117}$ C, “Church,” “p. 70,” fo. 1v.
} 
obedience" only having read and summarized the ensuing pages of the Discourse: his comment on "beleife of god in general" is an interlineation.

The Bodleian manuscripts of Locke's commentary on Parker do not refer to this position. They echo many portions of the Chapel Hill manuscript. "What fundamentall libertys of mankinde were invaded by the church of Rome," Locke asks again, in one of the Bodleian manuscripts. ${ }^{18}$ They also elaborate on queries that the Chapel Hill manuscript presents only elliptically. In the latter, Locke notes that Parker supposes Nonconformists to be "always in mistakes." As Locke adds, however, the knowledge of whether their practices or beliefs are erroneous is indeterminable in "indifferent" matters, which is precisely why they are "indifferent." The Bodleian manuscripts expand on this point by asking whether Parker supposes "the magistrates power to proceed from his being in the right."119 This would postulate a basis for the magistrate's authority-rectitude in theology-that is separable from merely "preserving peace." But how, Locke asks, can one resolve a contradiction between the imperatives of rectitude in theology and the imperatives of civil peace? The power to preserve the latter, the Bodleian manuscripts continue, "is by every sober man to be allowd." 120 But either it can extend to any religious belief that the magistrate considers dangerous to civil peace, a point that is not short of "Mr Hobbs's doctrine," or it cannot, in which case Parker concedes that there must be limits to the magistrate's authority. If those limits are determined by theology, the debate will return to the same impasse that characterizes the question of "indifferency." In place of arguing over what is or is not indifferent, Locke implies in the Chapel Hill manuscript, it is easier merely to stipulate a subject's "beleife of god in general."

The discovery of the Chapel Hill manuscript reveals that Locke had reached this conclusion by $c .1669$, where it had previously been thought that he had not contemplated it any earlier than c.1671, the point from which the Miltons had dated three manuscript additions to Locke's Essay Concerning Toleration. ${ }^{121}$ These alterations, the Miltons maintained, expressed a "very different outlook" to the Essay: "a significant shift away from the views that Locke had maintained in 1667 and towards those expressed in the Epistola de Tolerantia." 22 One of these alterations revealed Locke's hesitation to endorse the stance he had adopted in the "first draft" of the Essay, in which the magistrate was empowered to suppress religious dissent "if the professors of any worship shall grow soe numerous \& unquiet as manifestly to threaten disturbance to the state." 123 Instead, Locke deprived the magistrate of this power which, if consistently applied, would extend to any "things" which may "occasion disorder or conspiracy in a commonwealth." "All discontented \& active men must be removd," Locke reasoned, in a reductio ad absurdum, "\&

\footnotetext{
${ }^{118} \mathrm{O}_{2}$, "p. 24," fo. 7 r.

${ }^{119} \mathrm{O}_{2}$, "p 12," fo. $7 \mathrm{r}$.

${ }^{120} \mathrm{O}_{2}$, "p.11," fo. $7 \mathrm{r}$.

${ }^{121}$ ECT, 44. The additions appear in Bodleian Library, MS Locke c. 28, fos. 22r and 28v. The Miltons surmise that these additions were probably made only after Locke had copied a separate version of the Essay, which they date to a period no earlier than 1671 (ECT, 173-4, 187-8, 308-10).

${ }^{122}$ ECT, 44-5, 188.

${ }^{123}$ Ibid., 28, 44, 305.
} 
whispering must be lesse tolerated then preaching." ${ }^{124}$ Nonconformism, Locke adds, will only become seditious when it is persecuted. The premises of this position are absent from the earlier versions of the Essay, the Chapel Hill manuscript, and the Bodleian manuscripts of Locke's commentary on Parker, the latter of which expressly concede to the magistrate a power to "restraine seditious doctrines."125 The second and third alterations reported by the Miltons are different, in that both are anticipated by the Chapel Hill manuscript. First, in his revision to the Essay, Locke notes that the determination of "indifferency" is a matter for the individual believer: "when I am worshiping my god in a way I thinke he has prescribd \& will approve of I cannot alter omit or adde any circumstance in that which I thinke the true way of worship." ${ }^{126}$ Second, in his revision to the Essay, Locke notes that atheism is not entitled to toleration. Without "beleif of a deitie," Locke writes, "a man is to be counted noe other then one of the most dangerous sorts of wild beasts \& soe uncapeable of all societie." ${ }^{127}$ Locke's exception of atheists from toleration, reiterated infamously in the Epistola, is formulated here for the first time. Yet the minimalistic theism in the Chapel Hill manuscript-"beleife of god in general"-is a conceptual prerequisite of both approaches: the "individualistic"128 notion of "indifferency" expounded by the revised Essay and the conceit that the absence of a belief in God is an insuperable barrier to our coexistence in any civil society, a doctrine that Locke shared with Parker, and many others, but distinctively coupled with minimalistic theism as its corollary. We now know that both doctrines are present-if only inchoately-as early as 1669 .

This brings us to an obvious question about the Bodleian and Chapel Hill manuscripts: their purposes. Locke's queries and responses in the manuscripts are exiguous. It is possible that the manuscripts are only fragments of a larger corpus of notes on Parker, which Locke completed in 1669-70, but which are now not extant. The Essay Concerning Toleration is more far more elaborate and systematic, but it was nonetheless left unpublished. Every extant manuscript of the Essay terminates with a note that Locke would complete it "when I have more leisure." ${ }^{29}$ The Parker notes terminate in medias res, having reached only page 158 in its commentary on the Discourse.

Locke persistently hesitated to publish works that would attract attention to his political or religious sympathies. In April 1690, he complained bitterly to Philipp van Limborch (1633-1712) when the latter admitted that he had divulged Locke's authorship of the otherwise pseudonymous Epistola to a mutual friend. ${ }^{130}$ It is difficult to attribute this anger to anything other than what Peter Laslett once described as Locke's "obsessive" caution: the Epistola can hardly have endangered

\footnotetext{
${ }^{124}$ Ibid., 309.

${ }^{125} \mathrm{O}_{3}$, “p. 144," fo. 9r.

${ }^{126}$ ECT, 308.

${ }^{127}$ Ibid., 308.

${ }^{128}$ For an incisive contribution to the issue of Locke's "individualistic" tolerationism see Jacob Donald Chatterjee, "Between Hobbes and Locke: John Humfrey, Nonconformity, and Restoration Theories of Political Obligation," Locke Studies 19 (2019), 2-34, at 28.

${ }^{129} \mathrm{ECT}, 302$.

${ }^{130}$ CJL, 4: 61-62 (no. 1285).
} 
Locke in the year of its publication. ${ }^{131}$ It is possible that this same caution inhibited Locke from publishing against Parker. But other alternatives deserve consideration. In 1669-70 Locke became increasingly occupied in collaborating with Thomas Sydenham (1624-89) in medical practice, and he might not have had time to complete a full-scale response to either the Discourse or its Defence and Continuation. ${ }^{132}$ In early 1671 Locke commenced Draft $A$ of the Essay Concerning Human Understanding, again depriving him of the "leisure" to complete the Essay Concerning Toleration or a response to Parker. ${ }^{133}$ Richard Ashcraft has suggested that Locke's reading of the Discourse might have served as a fillip for Draft $A,{ }^{134}$ but it would be hard to associate the inspiration for Draft A with Parker's Discourse, tout court, in lieu of works within Locke's reach on the intellect, the soul, logic, medicine, and natural philosophy, to name only a few rival sources of inspiration for Locke's work. ${ }^{135}$ If Locke desisted in responding to the Discourse, it is probably because his interests had settled elsewhere. An alternative possibility is that the impetus behind a response had abated when Locke learned that Anglesey's circle was preparing a response of its own. Locke presumably shelved his notes on Parker and later spectated contentedly, as Marvell entered the fray.

\section{III}

The Chapel Hill manuscript is preserved in the Wilson Library of the University of North Carolina at Chapel Hill, where it forms part of a collection donated by Preston Davie (1881-1967), an American attorney, serviceman, and collector. ${ }^{136}$ The manuscript consists of two half-sheets, now disjoined, but apparently once forming a bifolium, each leaf measuring approximately $339 \times 228$ millimeters. The paper bears a countermark letter " $\mathrm{H}$ " (fo. 1) and watermark (fo. 2) of a

\footnotetext{
${ }^{131}$ For Locke's "obsessive" behavior in this connection see John Locke, Two Treatises of Government, ed. Peter Laslett, student edn (Cambridge, 1988), 6.

${ }^{132}$ In 1669 Locke wrote "De Arte Medica" as an expression of Sydenham's medical methodology (The National Archives, Kew, PRO 30/24/47/2, fos. 47r-56v). In 1670 Locke helped Sydenham draft a preface and dedicatory epistle to Ashley for a projected treatise on smallpox (PRO 30/24/47/2, fos. 57r and 60r$69 \mathrm{v})$. This treatise was apparently abandoned after Sydenham expanded the project to suppose that each year had its own epidemic "constitution" - a set of conditions that gave rise to a unique illness with a unique cure in that year. Acting as Sydenham's amanuensis, Locke helped transcribe Sydenham's medical essays over the next several months into a manuscript now known as the "Medical Observations," containing approximately fifty separable essays. Locke drafted at least seven of these at Sydenham's dictation and made fair copies of ten, while also correcting essays copied by Sydenham and by Locke himself. Locke made his own copies of at least thirty-four of these essays during this period, the last, "Epidemicall diseases of the year 1670," in the spring of 1671. For these details see Thomas Sydenham, Thomas Sydenham's Observationes Medicae (London, 1676) and His Medical Observations (Manuscript 572 of the Royal College of Physicians of London): With New Transcriptions of Related Locke MSS. in the Bodleian Library, ed. G. G. Meynell (Folkestone, 1991).

${ }^{133}$ John Locke, Drafts for the Essay Concerning Human Understanding, and Other Philosophical Writings, vol. 1, Drafts A and B, ed. Peter H. Nidditch and G. A. J. Rogers (Oxford, 1990).

${ }^{134}$ Richard Ashcraft, Revolutionary Politics \& Locke's Two Treatises of Government (Princeton, 1986), $106-11$.

${ }^{135}$ For this genre see R. W. Serjeantson, "Human Understanding' and the Genre of Locke's Essay," Intellectual History Review 18/2 (2008), 157-71.

${ }^{136}$ For Davie see the obituary in the New York Times, 22 May 1967, 43.
} 
horn and baldric in a coat of arms surmounted by a crown, followed, in vertical order, by a large " 4 ," and a combination of the letters " $W$ " and " $R$ "; this watermark closely resembles Heawood $2715 .{ }^{137}$ Locke folded each half-sheet vertically, forming two columns on each page. On the recto and verso of the first leaf, the left-hand column is headed "Magistrate" and the right-hand column "Church." On the recto of fo. 2, the left-hand column is headed "Magistrate" (again), but there is no heading on the right-hand column, and it appears that Locke's notes on the "Magistrate" continue from the bottom of the left-hand column on this page directly onto the right-hand column, and then conclude at the top of the left-hand column of fo. $2 \mathrm{v}$ (which has no heading). This columnar division of the manuscript resembles a similar arrangement in a manuscript of 1674, "Excommunication," in which Locke and an unidentified scribe divided his observations into two columns: "Civill Society or the State" and "Religious Society or the Church," on the basis that "There is 2 fold Society of which allmost all men in the world are Members and that from the 2 fold concernment they have to attaine a 2 fold happinesse, viz: That of this world and that of the other." ${ }^{138}$ This division might have appealed to Locke, in reading Parker, by revealing the limits of an attack on the Discourse as a species of Erastianism. Locke could follow Parker in disentangling the perspective of the "Magistrate" from the perspective of the "Church," and formulate a response to each, in turn and independently. ${ }^{139}$ The Chapel Hill manuscript is endorsed in Locke's hand (vertically in the left margin of fo. 2v): "S Parker of Toleration." Immediately underneath this endorsement is another, but in pencil ("Mr Locke's Notes"), possibly written by an auctioneer or a dealer in manuscripts.

The Davie Collection contains a second manuscript with a connection to Locke: a "Draft of act of Parliament for regulation of Elections" in the hand of Locke's friend, the Whig lawyer John Freke (1652-1717). ${ }^{140}$ The Wilson Library does not retain Preston Davie's records of acquisition, and the authors have not found a record of the manuscript's sale. ${ }^{141}$ But similarities to other Locke manuscripts permit a conjectural identification of its provenance. The "Draft" for the regulation of elections is closely related to three manuscripts now held in the Somerset Heritage Centre; these manuscripts discuss the electoral process, date from c.1699, and derive from the activities of Locke's friend Edward Clarke (16501710) as an MP for Taunton (1690-1710). ${ }^{142}$ The manuscripts are part of the Sanford papers: a collection formed by Clarke and his descendants, and purchased

\footnotetext{
${ }^{137}$ Edward Heawood, Watermarks, Mainly of the 17th and 18th centuries (Hilversum, 1950).

${ }^{138} E C T, 327$.

${ }^{139}$ We are grateful to Jeffrey Collins for this observation.

${ }^{140}$ The manuscript is endorsed "Draft of act of Parliament for regulation of Elections" (fo. $2 \mathrm{v}$ ) in an unidentified (probably nineteenth-century) hand.

${ }^{141}$ Our investigations of the Southern Historical Collection, 03406 in the University of North Carolina at Chapel Hill and the Preston Davie Papers, Mss1 D2856d in the Virginia Museum of History and Culture, Richmond, did not identify any evidence of the acquisition of either the commentary on Parker's Discourse or the "Draft."

${ }^{142}$ Somerset Heritage Centre, DD SSF/13/2/9 (formerly DD SSF/2785), DD $\backslash S F / 7 / 1 / 58$ (formerly DD $\backslash S F /$ 3842) and DD $\backslash S F / 13 / 2 / 49$ (formerly DDISF/3078). For these manuscripts see Mark Knights, "John Locke and Post-revolutionary Politics: Electoral Reform and the Franchise," Past and Present 213/1 (2011), 41-86.
} 
from the Sanford family of Nynehead, Somerset. ${ }^{143}$ Edward Clarke's daughters, Anne (1683-c.1744) and Jane (1694-1732), married into the Sanford family: Anne to William Sanford (c.1685-1718) and Jane to William's younger brother Henry (fl. 1717). In 1829 the Clarke estate at Chipley was bequeathed to Edward Sanford (1794-1871), the great-great-grandson of Anne Clarke and William Sanford. The electoral manuscripts were deposited in the Somerset Record Office between 1936 and 1942. ${ }^{144}$ The electoral manuscript in the Davie collection resembles the manuscripts in Somerset in handwriting, content and wording, and it is reasonable to conclude that it once formed part of the Sanford collection. ${ }^{145}$

The provenance of the new manuscript on Parker's Discourse appears to share a Sanford connection. In content, as we have argued, the new manuscript and the Bodleian manuscripts must have constituted a single collection of notes, preparatory to a response against Parker. A physical description of the manuscripts strengthens this surmise. The Bodleian manuscripts are presented on three bifolia, each containing a separate set of notes, each discontinuous with the other. It is possible that these three bifolia were grouped together by Locke, but there is no clear evidence to suggest it. The first bifolium (fos. 5-6) was folded vertically down the middle to produce two columns, each leaf measuring $294 \times 194$ millimeters. The watermark for this paper is an arrangement of grapes on columns, most closely resembling COL.016.1 in the Gravell Watermark Archive, ${ }^{146}$ and there is no visible countermark. It is a different type of paper, in other words, from the new manuscript. The text appears in the left-hand column of fo. $5 \mathrm{r}$, and continues on the verso of fo. $5 \mathrm{v}$ for approximately one-quarter of the page. The rest of fo. 5 and all of fo. 6 are blank, excepting an endorsement "Government / 〈illegible〉" written vertically in pencil on the far right of fo. $6 \mathrm{v}$, in a fairly modern hand, possibly dating from the early twentieth century, and probably supplied by an auctioneer or dealer. These notes present a paraphrase of Parker's account of the foundations of civil and ecclesiastical government in the first chapter of the Discourse. As this manuscript has no endorsement by Locke, we have designated it a title from the incipit ("Society is necessary ...") and assigned it the siglum $\mathbf{O}_{\mathbf{1}}$.

The second bilfolium (fos. 7-8) was folded vertically to produce a left-hand margin approximately one-quarter of the width of the page, each leaf measuring $230 \times 172$ millimeters. There is no visible countermark, but the watermark for this paper is the same as the new manuscript: closely resembling Heawood 2715. It is a different type of paper, in other words, from $\mathbf{O}_{1}$, but the same type of paper as the new manuscript. The text begins at the top of fo. $7 \mathrm{r}$ and continues onto fo. $7 \mathrm{v}$, ending approximately one-quarter of the way down the page; fo. $8 \mathrm{r}$ is blank and fo. $8 \mathrm{v}$ is endorsed by Locke " $\mathrm{Q}\langle\text { uerie }\rangle^{\mathrm{s}}$ On S. $\mathrm{P}\langle\operatorname{arker}\rangle^{\mathrm{s}}$ discourse / of toleration. 69." These notes present a set of queries on Parker's Discourse, with references to the places that prompted Locke's queries in the margin.

\footnotetext{
${ }^{143}$ For the Nynehead collection see A. C. Fraser, Biographica Philosophica: A Retrospect, 2nd edn (Edinburgh, 1905), 269-70.

${ }^{144}$ Items formerly catalogued DD $\backslash S F / 1-4510$ were deposited between these dates.

${ }^{145}$ For inventories of the Sanford library see Mount Holyoke College Library, MS 27, Sanford Family Papers, Box 4, vols. 5-8, Box 6, vols. 21-52; vol. 46, p. 15 lists "Locke John. Three volumes of Manuscript letters and other papers in the handwriting," without itemizing the "papers."

${ }^{146}$ The Thomas L. Gravell Watermark Archive (www.gravell.org, COL.016.1).
} 
Locke's handwriting in this manuscript is somewhat freer than was typical, and there are a number of changes of ink as Locke's queries progress. We have designated it a title from the endorsement ("Qs On S.Ps discourse of toleration") and assigned it the siglum $\mathbf{O}_{2}$.

The third bifolium (fos 9-10) was folded vertically down the middle to produce two columns, each leaf measuring $342 \times 233$ millimeters. The watermark for this paper is the same as the new manuscript and $\mathbf{O}_{2}{ }^{147}$ The left-hand column presents extracts from Parker, each with a page reference. The right-hand column is headed "Q," and presents queries salient to the adjacent extracts. There are only two such queries at the top of fo. 9r, the rest of the document being blank, save an endorsement "Religious / Government" written vertically in pencil on the far right of fo. $10 \mathrm{v}$, in a fairly modern hand, probably by the same auctioneer or dealer who endorsed $\mathbf{O}_{\mathbf{1}}$. As this manuscript has no endorsement by Locke, we have designated it a title from the incipit ("The vulgar are apt ...") and assigned it the siglum $\mathbf{O}_{3}$.

Though these three bifolia are held in the Bodleian Library, they were not acquired from the Lovelace family with the bulk of the Library's Locke Collection in 1947. ${ }^{148}$ The guardbook in which they are now preserved is an assortment of papers acquired or identified by the Bodleian Library between 1951 and 1957. The Parker manuscripts $\left(\mathbf{O}_{\mathbf{1 - 3}}\right)$ were purchased from Sotheby's on 15 March 1954. ${ }^{149}$ The sale catalogue gives no indication of the provenance of the manuscripts, but previous Sotheby's sales provide a clue. Papers related to Locke and Clarke were consigned to Sotheby's by E. C. A. Sanford (1859-1923) - a member of the Sanford family-in (at least) three sales before his death: 1913, 1915 and 1922. ${ }^{150}$ The 1922 sale contained a number of items on the subject of toleration: lots 866 and 867 consisted of Locke's autograph of the Essay Concerning Toleration, which is now preserved in the Huntington Library; lot 868 consisted of the Reasons for Tolerateing Papists Equally with Others, which is now preserved in the Greenfield Library at St John's College, Annapolis; and lot 871 consisted of the following miscellany: "LOCKE (J.) On the Clipping of Money, holograph MS, 2 pp. folio (Sept. 1694); An Essay concerning 'Whigs and Torys,' holograph MS, $13 / 4$ pp. 4to; Two short Notes in his hand concerning Government; Notes concerning Toleration in another hand, $1 \frac{1 / 4}{\text { pp. }} 4$ to." ${ }^{151}$ Several circumstances suggest that

\footnotetext{
${ }^{147}$ The countermark appears to be the letters "I A".

${ }^{148}$ For the accession of Locke's manuscripts to the Bodleian Library see Philip Long, A Summary Catalogue of the Lovelace Collection of the Papers of John Locke in the Bodleian Library (Oxford, 1959), i; and Long, "The Mellon Donation of Additional Manuscripts of John Locke from the Lovelace Collection," Bodleian Library Record 7 (1964), 185-93.

${ }^{149}$ Sotheby and Co., "Catalogue of Valuable Printed Books, Autograph Letters, Historical Documents" (15 March 1954), lot 265.

${ }^{150}$ Sotheby and Co., "Catalogue of Valuable Autograph Literary Manuscripts and Historical Documents" (28 July 1913), in Sotheby \& Co. Catalogues (hereafter SC) (Ann Arbor, MI, 1973-6), pt. III, Reel 40, lots 194-201; Sotheby and Co., "Catalogue of Valuable Books, Manuscripts and Autograph Letters, Including ... Letters of John Locke, the Property of Col. E. C. A. Sanford" (21 Dec. 1915), in SC, pt. III, Reel 45, lots 422-7; and Sotheby and Co., "Catalogue of Valuable Printed Books, Tracts and Pamphlets" (13 March 1922), in SC, pt. III, Reel 64, lot 868.

${ }^{151}$ The $S C$ series includes a copy of the auctioneers' catalogue; the latter bears a handwritten note to indicate that lot 871 was purchased by an individual surnamed "Melton." This was one of two lots that "Melton" purchased in the sale. The first (lot 870 ) was a manuscript now generally referred to as "On
} 
the last three items are $\mathbf{O}_{\mathbf{1 - 3}}$. First, it is clear that Clarke-and, subsequently, E. C. A. Sanford-owned manuscripts by Locke on the subject of toleration. Second, another manuscript from that sale, the Reasons for Tolerateing Papists Equally with Others, bears an endorsement in pencil ("Toleration") in a hand that resembles the hand of the modern endorsement on $\mathbf{O}_{\mathbf{1}}$ and $\mathbf{O}_{3}$. Finally, it is notable that both $\mathbf{O}_{1}$ and $\mathbf{O}_{3}$ bear endorsements with the word "Government," and are relatively "short"; $\mathbf{O}_{2}$ bears an endorsement with the word "toleration" and its text is one and a quarter pages in length. The catalogue indicates that the last item is not in Locke's hand, but, as we have noted, Locke's handwriting was somewhat freer in $\mathbf{O}_{2}$. An inexpert auctioneer might have mistaken it for "another hand." These concordances must indicate that the last three items in lot 871 were $\mathbf{O}_{1-3}{ }^{152}$ The latter therefore derived from the Sanford collection. Clarke's possession of three sets of manuscripts on the subject of toleration (Locke's Reasons, Locke's Essay, and $\mathbf{O}_{1-3}$ ) could point to a purposive act of acquisition on his part, but it is nonetheless probable that the manuscripts were deposited by Locke somewhat indiscriminately, as part of the "many papers" that he sent to Clarke in August 1683, before his departure into exile. Clarke ex hypothesi would have retained the manuscripts after Locke's return to England in February 1689. ${ }^{153}$

We have designated the Chapel Hill manuscript a title from the endorsement ("S Parker of Toleration") and assigned it the siglum C. C has a number of characteristics in common with $\mathbf{O}_{1-3}$, aside from sharing the same subject. $\mathbf{O}_{2}, \mathbf{O}_{3}$, and $\mathbf{C}$ appear to have the same watermark and might have derived from the same stock of paper. It is a reasonable conclusion that $\mathbf{C}$ and $\mathbf{O}_{1-3}$ share a provenance, and that all four manuscripts came from the Sanford collection. This hypothesis is somewhat supported by the fact that $\mathbf{C}$ is endorsed in pencil ("Mr Locke's Notes") in a hand resembling the endorsing hand in $\mathbf{O}_{1}, \mathbf{O}_{3}$, and the Reasons. This must suggest that the four manuscripts passed through the same chain of custody at some point, possibly as part of their shared consignment for sale. That the "Draft of an act of Parliament for regulation of Elections" mentioned above almost certainly derives from the Sanford collection lends circumstantial support to the conclusion that $\mathbf{C}$ was purchased with the "Draft" by Davie en bloc from the Sanford family, its representatives, or a dealer in manuscripts. ${ }^{154}$

\footnotetext{
Allegiance and the Revolution," which the Bodleian would acquire from Sotheby's in 1982 ("Valuable Autograph Letters, Literary Manuscripts and Historical Documents" (29 June 1982), lot 259) and assign the shelfmark MS Locke e. 18. This manuscript was first discussed in John Locke, Two Treatises of Government, ed. Peter Laslett, revised edn (Cambridge, 1967), p. 46 n. $\dagger$, first published in James Farr and Clayton Roberts, "John Locke on the Glorious Revolution: A Rediscovered Document," Historical Journal 28 (1985), 385-98; and now supplemented by Mark Goldie, "John Locke on the Glorious Revolution: A New Document," History of Political Thought 42/1 (2021), 74-97. The location of the first two items from lot 871, "On the Clipping of Money" and "An Essay Concerning 'Whigs and Torys'," is presently unknown. The latter was resold by Sotheby's in "Valuable Autograph Letters, Literary Manuscripts and Historical Documents" (2 June 1982), lot 260. Felix Waldmann, "New Manuscript Fragments by John Locke," Notes and Queries, forthcoming.

${ }^{152}$ Correcting the assertion made in Waldmann, "New Manuscript Fragments by John Locke".

${ }^{153} C J L$, 2: 600-3 (no. 771).

${ }^{154}$ None of the catalogue listings in the 1913, 1915 or 1922 Sotheby's sales from the Sanford collection describe manuscripts that unambiguously match those in the Preston Davie Collection. The listing for lot 874 in the 1922 sale does describe "Papers related to Edward Clarke of Chipley; with others of
} 
We cannot assume that the current dispersal of these manuscripts is anything more than an accident of transmission. There is no basis to assume that $\mathbf{O}_{\mathbf{1}}-\mathbf{3}$ should be considered as a single unit, or that they were grouped by Locke in a specific order, or deliberately to exclude C. C examines the preface and first 158 pages of Parker's Discourse, making it significantly longer and more comprehensive than $\mathbf{O}_{2}$ and $\mathbf{O}_{3} \cdot \mathbf{O}_{2}$ examines pages $11-29$ and $\mathbf{O}_{3}$ examines pages 144-53. Moreover, there is no clear reason why Locke ceased taking notes at page 158 of Parker's work, in the middle of Chapter 4. The Discourse comprised eight chapters and the subject matter did not drastically change in the latter half of the book. There are changes of ink in both $\mathbf{C}$ and $\mathbf{O}_{2}$, but there is no clear evidence that Locke was making notes on both manuscripts at the same time, using the same implement. This would indicate that Locke set aside his work on the Discourse, which in turn suggests that he made the notes in $\mathbf{C}, \mathbf{O}_{2}$, and $\mathbf{O}_{3}$ at roughly the same time, perhaps taking a new sheet for $\mathbf{O}_{2}$ and $\mathbf{O}_{3}$ to make notes when his more comprehensive notes $(\mathbf{C})$ were not ready to hand. $\mathbf{O}_{1}$-written on a different type of paper-presents neither notes nor queries, but rather paraphrases the first chapter of the Discourse (pages 1-64). It might have been written before $\mathbf{O}_{2-3}$ and $\mathbf{C}$, as a first attempt to summarize Parker's arguments, or it might have been written after $\mathbf{O}_{2-3}$ and $\mathbf{C}$, as a preparatory sketch for a longer confutation. Our inclination is to favour the former possibility: Locke began a paraphrase, returned to make notes in more detail, and then set the entire project aside. But this reconstruction should be considered no more than a plausible hypothesis. In the transcription below, the manuscripts will be presented together for the first time, and in the following order:

C "S Parker of Toleration" (Southern Historical Collection, 03046, Folder 323).

$\mathbf{O}_{2}$ "Q $\mathrm{Q}^{\mathrm{s}}$ On S.P $\mathrm{P}^{\mathrm{s}}$ discourse of toleration" (MS Locke c. 39, fos. 7-8).

$\mathbf{O}_{3}$ "The vulgar are apt ..." (MS Locke c. 39, fos. 9-10).

$\mathbf{O}_{1}$ "Society is necessary..." (MS Locke c. 39, fos. 5-6). ${ }^{155}$

\section{IV}

\section{Editorial conventions}

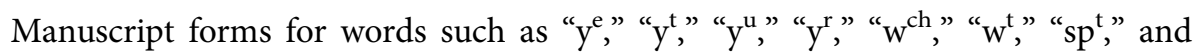
"ag" have been replaced by the usual printed forms, as have suffixes such as "$\mathrm{m}^{\mathrm{t}}$ :" [-ment] and "-cōn" [-tion]. Contractions and abbreviations such as " $\mathrm{K}$ "

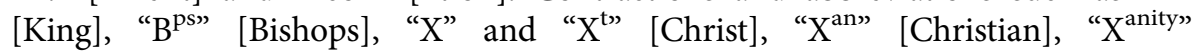
[Christianity], "S $\mathrm{ts"}$ [Saints], "nāāl" [natural], "meū" [meum] and "ib" [ibidem] have been silently expanded. Locke's "i.e" has been rendered as "i.e.". Citations of Parker have only been provided in those instances where Locke's citations are missing, incomplete, or erroneous. $\mathbf{C}, \mathbf{O}_{3}$, and $\mathbf{O}_{1}$ typically provide Locke's paraphrase of Parker's text, rendering the presentation of Parker's own text otiose. In

Somersetshire interest (a large parcel)," which could conceivably have contained the items acquired by Davie. Yet this seems unlikely, given the attribution of $\mathbf{C}$ to Locke in the pencil endorsement. It is possible that the Davie manuscripts were consigned for sale at Sotheby's then withdrawn from auction and sold by private treaty, or by some other route.

${ }^{155}$ Our transcription of $\mathbf{O}_{1-3}$ alters the format of the transcription in ECT, 57-70, 192-4, 322-6, but it does not substantively alter the wording of the transcription. 
$\mathrm{O}_{2}$, and in some instances in $\mathbf{C}$, quotations from Parker have been provided to contextualize Locke's comments. $\mathbf{O}_{1}, \mathbf{O}_{2}$, and $\mathbf{O}_{3}$ each present material also covered in $\mathbf{C}$. In addition, $\mathbf{O}_{2}$ and $\mathbf{O}_{1}$ also overlap to a certain extent. Cross-references between each of the manuscripts have been provided where appropriate. These references use the siglum of the manuscript, the column in which the reference appears (in the case of $\mathbf{C}$ ), the page number Locke cited (if any), and the folio on which the reference appears (since there is no duplication of folio numbers amongst the manuscripts, there is no need to cite the full shelfmark to distinguish them).

\author{
Editorial signs \\ italics scribal addition \\ word scribal deletion \\ $\mathrm{m} b$ ad scribal cancellation by superimposition of correction \\ a () the letter "a" is conjectural; the next is indecipherable \\ \langle\rangle editorial insertion or substitution in a text \\ \{\} editorial excision
}

\title{
Transcriptions
}

C-“S Parker of Toleration"

University of North Carolina at Chapel Hill, Wilson Library, Southern Historical Collection, 03406 (Folder 323). A series of notes with occasional queries on Samuel Parker's A Discourse of Ecclesiastical Politie in Locke's hand.

[fo. $1 r]$

Magistrate

Sects, partys, \& zeale in the outward performances of religion destroys humane society peace \& common love pref p. vi vij viij ix

Religious sects when in power tyranicall \& cruell when out of power full of malice slander \& censure p ix \& are neither good subjects nor good neigbours. p. $x$

True piety advances the content interest \& reputation of men $\&$ is advantageous to the peace \& happynesse of the world. p. xxxix

Conscience (which is every mans perswasion or judgment of his owne actions.) being acted in most by absurd principles vices. ${ }^{158}$ passions will destroy the power of
Church.

They that confesse in their prayers particular heynous crimes either trifle with god or deserve punishment xix $^{156}$

Liberty of conscience inconsistent with government \& peace. \& therefor not to be allowd though it promote trade which is not to be valued with peace $\mathrm{xlvi}^{157}$

To erect \& incourage Tradeing combinations is only to build soe many nests of factions \& Sedition p. xlix

Fanaticks not $1 / 20 \mathrm{p}$ xlix

Fanatick fundamentall principles incline them to perverse \& restlesse dispositions. p. 1 \& to overturne the government: ibidem \& wealth incourages their presumption ibidem ${ }^{159}$

\footnotetext{
${ }^{156}$ Parker, Discourse, xix-xx.

${ }^{157}$ Ibid., xlvi-xlviii.

${ }^{158}$ Locke leaves a noticeable gap between the terminal word in the sentence and the full stop.

${ }^{159}$ Ibid., 1-li.
} 
governors if it be exempt from the command of governors to be obeyd. p. $7 .^{160}$ \& bring in Anarchy wherein every one does what is good in his owne eyes. p. 7.

Magistrates power not supreme if it be to submit to the conscience of the subject p. 8 .

It is necessary to the peace of governments that the magistrate should have power over the conscience in matters of religion ${ }^{161}$

$1^{\circ}$ Because Religion haveing soe strong an influence over the minds \& actions of men the magistrate must have power to binde their subjects to that religion they he apprehends to be most advantageous to publique peace or else he wants power to secure the peace $12^{163}$ men being more furious wild \& ungovernable in their religious opinions p. $123^{165}$ zeale for the glory of god is wont to excuse \& justifie any enormity, ${ }^{167}$ all nations have felt the misery of a holy war. 14 . The vulgar most prone to superstition. noe vice to which the vulgar is more prone then to superstition or debaucht ${ }^{168}$ conceptions of god $\&$ his worship nor any that more inclines them to a seditious temper p. 15 the rankest passions becomeing then zeale for the glory of god ibidem, zeale sacred, \& nothing sacred excessive 16 v. ibidem. pl: Erroneous consciences are bold enough to out face authority, but men of scandalous lives being deba condemned by their owne consciences as well as the law can have noe thing to beare them up against the will of their superiours \& restraint of government 17.

Wherever the government gave liberty to mens imaginations they were suddainly over run with numberless divisions \& subdivisions of sects. $22 .^{171}$

The affairs of religion are subject to the Civil power or to none because that is supreme \& can have noe other power either superior or equall 25 . for then a man might be subject to contradictory commands 26 .

The supreme government of every commonwealth where ever lodgd must of necessity be universal absolute \& uncontrouleable in all affairs whatsoever that
Noe way to setlement but by suppresseing dissensions in religious worship, because the generality of mankinde being erroneous \& foolish have the most wild \& unreasonable conceits concerning religion \& therefor their consciences require the severest government because such men haveing great zeale noe checks of conscience \& if their attempts faile have the rewards of Saints \& martyrs boggle at noe mischeif. $\mathrm{li}^{162}$

Thus the world always has \& must be governd liiij Uniformity is the foundation of peace $\&$ is to be establishd by the severe execution of severe laws ibidem

Lesse hazard to give liberty to mens vices then their consciences $l^{164}$

Conscience hath a great influence on mens actions whether it guid to good bad or indifferent p. $4^{166}$

Conscience which is every ones perswasion Because men are apt to mistake in religion, \& perswasions in religion produce zeale \& that zeale is turbulent therefor the magistrate is concernd with the severest inflictions to punish mistakes in religion \& with severity either to prevent their rise or suppresse their growth $\mathrm{p} 18^{169}$

Because wilde \& ffanatic consciences are too head strong to be curbd with ordinary severity therefor their restraints must be managed with the greatest strictnesse. p. 21.

Ecclesiasticall laws have generally proved ineffective instruments of uniformity because either weakend through want of Execution or in a manner canceld by the opposition of civil constitutions. $^{170}$

$1 \mathrm{He}$ defines not religion $\mathrm{L}$

2 He sets noe bounds to conscience how far it is or is not to be tolerated $\mathrm{L}$

3 Where he says that the magistrate is to use severity against dissenting consciences he supposes them always in mistakes Q What those fundamental libertys of mankinde are which the church of Rome hath invaded $24 .{ }^{172}$

\footnotetext{
${ }^{160}$ Ibid., 7-8.

${ }^{161}$ Ibid., 10. See also $\mathbf{O}_{2}$, “p.11,” fo. $7 \mathrm{r}$.

${ }^{162}$ Ibid., li-liii.

${ }^{163}$ See also $\mathbf{O}_{2}$, “p 12," fo. $7 \mathrm{r}$.

${ }^{164}$ Parker, Discourse, liv-lv.

${ }^{165}$ Ibid., 12-13.

${ }^{166}$ Ibid., 4-6.

167 "enormity,": this word is indistinct in the manuscript, but Parker, Discourse, 14, has "Enormity."

168“ $\{$ debauch\} $\langle$ debaucht $\rangle "$ : following Parker, Discourse, 15.

${ }^{169}$ See also $\mathbf{O}_{2}$, "p. 18," fo. $7 \mathrm{r}$; and $\mathbf{O}_{1}$, fo. 5 r.

${ }^{170}$ Parker, Discourse, 19-20.

${ }^{171}$ See also $\mathbf{O}_{2}$, "p 21," fo. $7 \mathrm{r}$.

${ }^{172}$ See also $\mathrm{O}_{2}$, “p. 24 ," fo. 7 r.
} 
concern the interest of mankinde \& ends of government $27 .^{173}$

Society necessary to the preservation of mankinde. government to Society a supreme power to government to discide controversy p. $28^{174}$

All government paternall authority, the children borne subjects. $29^{175}$ \& ecclesiastical also. $^{176}$

$$
\text { [fo. } 1 v \text { ] }
$$

\section{Magistrate}

Publique worship being as necessary in societys as publique justice the power thereof can belong only to him in whome the supreme power resides who haveing authority to assigne to each subject his proper function the exercise of preisthood he may either transfer to an other or reserve to him self p. $32^{177}$

The supreme soveraigne power was still invested with the supreme preisthood for the first 2500 years ibidem ${ }^{179}$

The Kings of Judea exercised supremacy in all ecclesiasticall causes. $32 .^{180}$ \& the christian magistrate hath noe less right 33 .

Christ came to establish new laws of morality not to set up new models of pollicy the government of the world he left as he found it $34 .{ }^{182}$ not limiting the prerogative of princes who being vested with the government of religion by a natural antecedent right it doth still belong to them. 34

The end of government the peace \& tranquility of the publique. $35^{184}$

Kings are appointed that under them we may lead a quiet life in all godlinesse \&c ergo the propagation of godlynesse is as much the duty of governors as preservation of justice. 36 .
Q. What are the due bounds of ecclesiastical authority 25 [fo. $1 v$ ]

\section{Church:}

Christ inforced his commandments with threatnings of eternity which carry with them more compulsion upon mens consciences then any civil sanction can. He forbore secular compulsion not because improper but because he was not vested with it. 42 .

Q If the whole duty of man be either to god his neigbour \& himself \& that to god is either praise or prayer prayse being a sort of but the vertue of gratitude to god \& prayer if for $\langle\text { our }\rangle^{178}$ selves is others is Charity if for our selves is either for enjoyments of this life or some vertuous qualitys Soe that all dutys of devotion (except gratitude) being not essentiall parts of religion but are only in order to it as they tend to the practise of vertue. $\&$ p. $70 .^{181}$ Q. why soe much stress \& stir about ceremonys more then needs L.

Sects \& divisions ariseing in Christianity we owe the preservation there of to the Christian magistrate interposeing his authority. $53 .{ }^{183}$

The magistrate has power to binde laws on the consciences of men concerning the most weighty concerns of religion i.e. dutys of morality. $70^{185}$

$(Q R$. he binds not laws concerning the dutys on

\footnotetext{
${ }^{173}$ See also $\mathbf{O}_{2}$, “p. 25," fo. $7 \mathrm{r}$.

${ }^{174}$ See also $\mathbf{O}_{1}$, fo. 5 r.

${ }^{175}$ See also $\mathbf{O}_{2}$, “p. 29," fo. $7 \mathrm{r}-\mathrm{v}$ and $\mathbf{O}_{1}$, fo. $5 \mathrm{r}$.

${ }^{176}$ Parker, Discourse, 31.

${ }^{177}$ Ibid., 31-2.

178“ $\{$ our $\}\langle$ eur $\rangle$ ": Locke originally wrote “our selves is", and meant to delete the phrase, but forgot to delete
} "our."

${ }^{179}$ See also $\mathbf{O}_{1}$, fo. $5 \mathrm{r}$.

${ }^{180}$ See also $\mathbf{O}_{1}$, fo. $5 \mathrm{r}$.

${ }^{181}$ Parker, Discourse, 69-70.

${ }^{182}$ Ibid., 33-4.

${ }^{183}$ Ibid., 52-3.

${ }^{184}$ See also $\mathbf{O}_{2}$, “p. 25 ," fo. $7 \mathrm{r}$.

${ }^{185}$ Locke gives an incorrect page number. Parker, Discourse, 77: “ $\$ 4$. 'Tis certain then, That the Duties of Morality are the most weighty and material concerns of Religion; and 'tis as certain, That the Civil Magistrate has Power to bind Laws concerning them upon the Consciences of Subjects."

${ }^{186}$ Locke gives an incorrect page number. Parker, Discourse, 77: "And therefore is it not strange, that when the main Ends and designs of all Religion are avowedly subject to the Supreme Power, that yet men should be so impatient to exempt its means and subordinate Instruments from the same Authority?" 
Christ gave severe injunctions to secure Christians to all the commands of lawfull superiours except when they run directly crosse to the interest of the gospell 37 .

That noe magistrate may compell men to any part of the doctrine worship or discipline of the Gospell will remain to be proved till they can produce some expresse prohibition of our Saviour. p. 41. to restraine him p. 41. for all the ways Christ hath apointed for the propagation of religion were prescribd to subjects \& not governors $^{187}$

CChrist $^{188}$ \& his Apostles acted in the capacity of subjects \& soe could neither use them selves nor impart to others any coercive power. 41. for the propagation of their doctrine

Because threatnings relateing to another life were not sufficient to attein the ends of discipline miraculous punishments attended excommunication which ceased not till Christianty haveing gaind the Empire \& when it became the Imperial religion then began its government to resetle where nature had placed it $48^{190}$ \& hence forward though the preist commissioned by Christ had the exercise still of the ministerial function the exercise of its authority \& jurisdiction was restored to the Imperial diadem \& the Bishops became ministers of state as well as religion haveing noe secular power but what was derived from the prince. 49. Soe that Bishops neither have nor ever had any temporal authority but as the King's ecclesiastical judges appointed by him to governe the affairs of religion. $\underline{50}$ the government of the church devolved upon the royall authority. $\underline{50}^{193}$

$$
\text { [fo. 2r] Magistrate }
$$

Moral vertue the cheif part of religion Religion consisting in noething else but either the practise of virtue or the use of those meanes that contribute to it 69

The Christian Emperors from Constantine de facto exercised ecclesiastical jurisdiction. $\underline{50}^{194}$

The multitude more apt to disturbe government by superstition then licentiousnesse 78 the conscience but inforces obedience by penaltys on such who obey not their consciences JL.)

\& Therefor the main ends of religion being subject to the supreme power the meanes \& subordinate instruments cannot be exempt from the same authority. $70^{186}$

The businesse end of man is to live happily here \& prepare himself for happynesse hereafter. The means are moral vertue \& devotion because of the variable changablenesse of cases \& circumstances god hath left both these in the appointed the magistrate to determine of both these \& soe the circumstances \& outward expressions of Divine worship became rites religious rites being appointed by the magistrate where they doe not contradict the end of religion \& such noe human power can command which is to expresse our honourable opinion of god \& advance vertue $\& c^{189} \mathrm{Q}$ Here he uses devotion in one part \& applys it to ceremonys in the other part of his argument. JL.

Idolatry is either giving right worship to a wrong object or vice versa or representing an infinite majesty by images of finite things \& soe reflect disparagement on some of the attributes of god. 82 .

In morality \& divine worship there are some rules of good \& evil of an eternall \& unchangeable obligation \& these can never be alterd by any humane power. There are other rules of duty that are alterable \& depend cheifly upon humane contract \& positive laws of Kingdoms. ${ }^{191}$ Tis absolutely necessary to make returns of duty to the Creator from which no humane power can restrain it $a$ man but the outward expressions are subject to the constitutions of different nations unlesse that they either countenance vice or disgrace the deity $834.83 .{ }^{192}$

\footnotetext{
${ }^{187}$ Parker, Discourse, 40-41. The passage Locke cites here precedes that which he cites immediately prior to it.

188 " $E X^{t \text { " }}$

${ }^{189}$ Parker, Discourse, $80-82$.

${ }^{190}$ Ibid. $43-8$. See also $\mathbf{O}_{1}$, fo. $5 \mathrm{v}$.

191 "Kingdoms. $\{$. $\}$ ": an illegible mark and full stop with no basis in Parker's text, excised for sense.

${ }^{192}$ Parker, Discourse, 83-5.

${ }^{193}$ See also $\mathbf{O}_{1}$, fo. $5 \mathrm{v}$.

${ }^{194}$ Parker, Discourse, 50-51.
} 
Greater danger of the magistrates erreing in morality then ceremonys 78

Q Here morality opposd to Ceremonys not opinion religion $78 \mathrm{JL}$

If the magistrate has soe great power over mens consciences as to determin particular acts of virtue (viz the law bounds meum \& tuum ${ }^{195}$ which determins justice) much more certainly may he declare the use \& decency of a few circumstances $78.80^{196}$

Q In the first chapter he seems to use religion most commonly both for opinions \& outward worship or the circumstances of it in $2^{\mathrm{d}}$ for ceremonys only.

The magistrates over jurisdiction over mens consciences in emergent \& secondary laws of morality \& the subordinate \& instrumentall rules of worship is of the same extent $85^{197}$ \& freedom from laws in one as well as other tend to Anarchy \& confusion ${ }^{198}$

Conscience i.e. opinion or judgment concerning the goodnesse or ill even of civil laws as well as all other things is absolutely free, $1^{\circ}$ tbecause it is out of the reach of \& cognizance of the magistrate $z^{\ominus}$ because the understanding in its owne nature is free $23^{\circ}$ because it hath noe influence upon human the good or evill of humane society the proper object of government but all actions whether moral or religious me are under the cognizance of lawes because under there in the peace of mankinde is concernd 89. ${ }^{199} \mathrm{Q}$ Whether opinions doe not are not capable of haveing any influence upon the Publique good or ill of man kinde?

Though actions be capable of haveing any influence upon the publique good or ill of mankinde be liable to the determination of humane laws yet the law of god will not suffer them to be determind farther then is requisite to the ends of government $93^{200}$

All christian liberty relates only to our inward judgment 95 . \& if that be inviolate it matters not what restraints are laid upon our outward actions.

$\mathrm{Q}$ whether all ${ }^{201} \$ 2^{\mathrm{d} 202}$ relate to any thing be true in any thing but barely what I judg in its self indifferent but what becomes of those things I judg unlawfull

195“meum \& tuum": the distinction between what is mine or one's own and what is yours or another's. OED, “meum," $n .^{2}$.

${ }^{196}$ Parker, Discourse, 78-80.

${ }^{197}$ Ibid., 85-6.

${ }^{198}$ Ibid., $86-7$.

${ }^{199}$ Ibid., 89-90.

${ }^{200}$ Ibid., 93-4.

201 "all \{ \}": an illegible mark that was likely deleted, excised for sense.

${ }^{202}$ Parker, Discourse, 92-5. 
Christian liberty consists in the freedom of judging things to be indifferent which are in their owne nature indifferent \& in being exempt from the obligation of Mosaical ceremonys which by that law were obligatory. $96^{203}$

The essence \& whole substance of religious worship is transacted within in the minde of man $\&$ is noe thing but a grateful sense \& temper [ fo. $2 r$ column 2] of minde towards the divine goodnesse 98. external worship but the instrument to expresse this inward gratitude \& veneration of which god hath prescribd noe particular formes because any one would be inconsistent with the variety of customs \& fashions of the world ${ }^{204}$

God hath left al rites \& ceremonys of externall service (except the sacraments federal $^{205}$ ones) to the discretion of the church. $104 \&$ all those practisd in the Christian church depend on the authority of the civil power ${ }^{206}$

Where a religion is establishd by the laws whoever openly refuses obedience, rebells against the government ${ }^{207}$

Q Whether haveing in the foregoing $\$ \$ s$ \& this spoken only of ceremonys he doth not here call ceremonys religion or else his argument is not good

Significant ceremonys senselessly clamourd against when tis the only use of ceremonys worship being only an outward signe of inward honour 106. noe more exceptions against significant ceremonys then words, \& their signification wor is equally arbitrary \& therefor the publique may injoyne such as are not customary marks of contempt $107 .^{208} \&$ therefor if the magistrat positive command or publique consent doe not determin what actions shall be pub visible signes of honour there can be noe publique worship 108

In things of essential rectitude determind by the law of nature as to beleive a god the truth of the gospel \&c it is our duty to disobey the contrary laws of the magistrate which is not from our owne freedom but our obedience to god the higher power $113 .^{209}$

Q. Whether p. 126 his argument be not good to prove that god at first made us stockings \& shoes \& immediately bestowed on

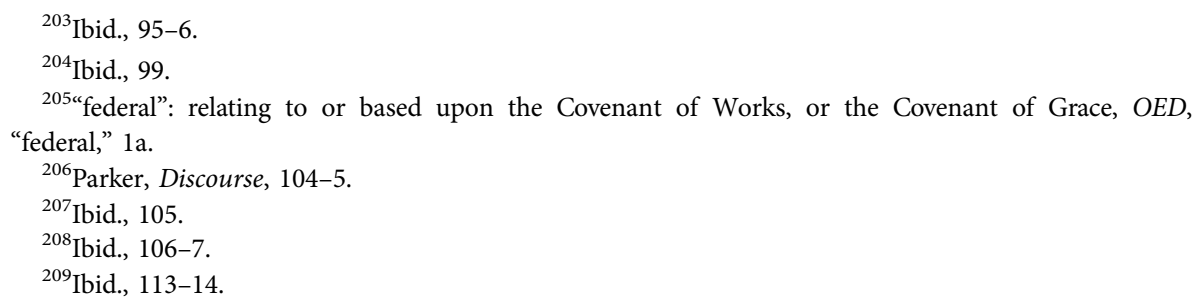


mankinde all those advantages which we now imagine to be the inventions of humane wit? ${ }^{210}$

Men are not naturaly in a state of war. because by god appointed to happynesse. happynesse not to be had without society. society not to be mainteind without freindship justice \& some aime at the publique good of man kinde. $121 .^{211}$ Men also are never borne out of society nor government ${ }^{212}$

Religion supports government because besides that noe without that there can be noe obligation to obedience but self interest $140 .^{213}$ $Q$ whether this extends any farther then a beleife of god in general. but not of this particular worship

Religion back $\langle$ ed $\rangle$ with the apprehensions of hell \& heaven hath more force on the minds \& actions of men then any secular interest can 142

The magistrate is concernd to take care what epinions doctrines of religion are taught within their religion dominions since they soe mightily dispose men to quiet $\&$ or tumult $144^{214}$ tis his interest to propagate doctrines of obedience Q Whether this proposition doth infer that either the teachers will preach what ever the magistrate directs, or that people will or at pleasure can assent to such doctrines as are taught

The Vulgar are apt to be mistaken in religion, zeale is very ungovernable, \& religion without prudence produces sad effe horrid effects p. 144 $\& c^{215}$

There is the same phanatick spirit that mixes its self with all the religions in the world $153^{216}$

A beleif of invisible power is soe far from aweing being religion enough to awe men to obedience that unlesse it be temperd with vertue \& prudence it rather tends to make the multitude ungovernable 155

The factions inof religion are ever the most seditious \& the lesse material their difference the more implacable their hatred therefor to permitt different sects of religion in a common wealth is only to keepe up soe many pretenses for publique disturbance 155

${ }^{210}$ Ibid., 126-7: "and therefore that the Well-being of the World is to be entirely attributed to mans Wit, and not to Gods Providence, who sent his Creatures into it in such a condition as should oblige them to seek their own mutual ruine and destruction; so that had they continued in that state of War he left them in, they must have lived and died like Gladiators, and have unavoidably perish'd at one time or other by one anothers Swords; and therefore that Mankind owe the comfort of their lives not at all to their Creator, but entirely to themselves."

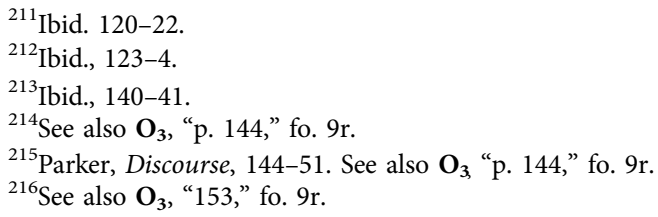


[fo. 2v]

every faction in religion is at open war with

defiance with every faction, they are always in a

state of war 156

All dissenting partys are possessd with a furious

zeale to promote their owne perswasions 157 .

If the prince goe about to ballance the partys

one against another he takes the readyest way to

forfeit his interest in all $^{217}$

S Parker of Toleration ${ }^{218}$

Mr Locke's Notes ${ }^{219}$

\section{$\mathrm{O}_{2}$ - "Qs On S.Ps discourse of toleration"}

Bodleian Library, MS Locke c. 39, fos. 7-8. A series of queries on Samuel Parker's A Discourse of Ecclesiastical Politie in Locke's hand.

$$
\begin{aligned}
& {[f \text { fo. } 7 r]} \\
& Q^{220} \\
& \text { p.11. }{ }^{221} \text { S.: } 4.5 .6 .8 \\
& .10
\end{aligned}
$$

p 12 .
Whether ${ }^{222}$ Prooves anøey thing but that the magistrates businesse being only to preserve peace, those wrong opinions are to be restrained that have a direct tendency to disturbe it? and this is by every sober man to be allowd $\mathrm{d}^{223}$

Whether assigneing those ill effects that follow to mistakes. p. $18^{224}$ wrong notions of god \& his worship ${ }^{225}$ he does not suppose the magistrates power to proceed from his being in the right.

Whether by binde the subject to his religion, ${ }^{226}$ he means that whether the magistrates opinion be right or wrong he has power to force the subject to assent to renownce his owne opinions however quiet \& peaceable \& declare

${ }^{217}$ Parker, Discourse, 158.

${ }^{218}$ Vertically down the left-hand side of the page.

${ }^{219}$ Horizontally in pencil beneath Locke's endorsement in an unknown early twentieth-century hand, possibly an auctioneer or a dealer in manuscripts.

${ }^{220}$ Addition in significantly darker ink.

${ }^{221}$ Parker, Discourse, 11-12: “\$4. First then 'tis absolutely necessary to the Peace and Tranquillity of the Commonwealth, which, though it be the prime and most important end of Government, can never be sufficiently secured, unless Religion be subject to the Authority of the Supreme Power, in that it has the strongest influence upon humane Affairs; and therefore if the Sovereign Power cannot order and manage it, it would be but a very incompetent Instrument of publick happiness, would want the better half of it self, and be utterly weak and ineffectual for the ends of Government." See also C, "Magistrate," “12," fo. 1r.

${ }^{222}$ Addition in significantly darker ink.

223 "and this is by every sober man to be allowd" in significantly darker ink.

224"mistakes. p. 18" addition in significantly lighter ink, similar to "\& ... Martyrs." below. These additions were probably made at the same time. Parker, Discourse, 18: "And therefore seeing the multitude is so inclinable to these mistakes of Religion, and seeing, when they are infected with them, they grow so turbulent and unruly, I leave it to Governours themselves to judge, whether it does not concern them with as much vigilance and severity either to prevent their rise or suppress their growth, as to punish any the foulest crimes of Immorality?". See also C, "Church," "p 18," fo. $1 \mathrm{r}$, and $\mathbf{O}_{\mathbf{1}}$, fo. $5 \mathrm{r}$.

${ }^{225}$ Parker, Discourse, 12: "This leads or drives them any way, and as true Piety secures the publick weal by taming and civilizing the passions of men, and inuring them to a mild, gentle and governable spirit: So superstition and wrong notions of God and his Worship, are the most powerful engines to overturn its settlement," following on immediately from the quotation in n. 221 above.

${ }^{226}$ Parker, Discourse, 12: "And therefore unless Princes have Power to bind their Subjects to that Religion that they apprehend most advantageous to publick Peace and Tranquillity, and restrain those Religious 
assent \& consent to those of the magistrate? \& if soe why Christ \& the Apostles directed not their discourses, \& addressed their miracles to the princes \& magistrates of the world to perswade them, whereas by preaching to \& converting the people they according to this doctrine under a necessity of being either Seditious or Martyrs. ${ }^{227}$

p $21^{228} \quad$ Whether subdivision of opinions into small sects be of such danger to the government

p. $24^{229}$

p. $25^{230} \$ 10$

p. $29^{232} \$ 11$
What fundamentall libertys of mankinde were invaded by the church of Rome that will not be in the same condition, accord under the civill magistrate according to his doctrine? since the power of the church of Rome was allowd, \& their decrees inforcd by the will of the civill magistrate

The end of government being publique peace tis noe question the supreme power us must have an uncontroulable right to judg \& ordeyne all things that may conduce to it? ${ }^{231}$ but yet the question will be whether Uniformity establishd by a law be (as is here supposd) a necessary means to it? i.e. whether it be at all dangerous to the magistrate that he beleiveing free will, his some of his subjects should beleive predestination, or whether it be nece more necessary for his government to make laws for weareing surplices, then it is for wearing vests?

Whether allowing the paternall right of government (which is asserted not proved) that paternall monarchy descended $[f o .7 v]$ upon death of the $\mathrm{fa}\left\langle\mathrm{th}_{\mathrm{fer}} \mathrm{er}^{23}\right.$ it

mistakes that tend to its subversion; they are no better than Statues and Images of Authority, and want that part of their Power that is most necessary to a right discharge of their Government," following on immediately from the quotation in n. 225 above. See also C, "Magistrate," "12," fo. 1r.

227 " $\&$ if soe why Christ ... either Seditious or Martyrs." in a significantly lighter ink, similar to "mistakes. p. 18" above; these changes were probably made at the same time.

${ }^{228}$ Parker, Discourse, 21-2: " $\$$ 8. For if Conscience be ever able to break down the restraints of Government, and all men have Licence to follow their own perswasions, the mischief is infinite, and the folly endless ... Insomuch that there never yet was any Common-wealth, that gave a real liberty to mens Imaginations, that was not suddenly over-run with numberless divisions, and subdivisions of Sects: as was notorious in the late Confusions, when Liberty of Conscience was laid as the Foundation of Settlement." See also C, "Magistrate," "22.," fo. 1r.

${ }^{229}$ Parker, Discourse, 24: "and because the Church of Rome by her unreasonable Impositions has invaded the Fundamental Liberties of mankind, they presently conclude all restraints upon licentious Practices and Perswasions about Religion under the hated name of Popery." See also C, "24.," fo. 1r.

${ }^{230}$ There is nothing on Parker, Discourse, 25, that matches the argument Locke discusses, but later (Parker, Discourse, pp. 27-8, \$10) Parker does state, "And therefore Affairs of Religion being so strongly influential upon Affairs of State, and having so great a power either to advance or hinder the publick felicity of the Common-wealth, they must be as uncontroulably subject to the Supreme Power as all other Civil Concerns; because otherwise it will not have Authority enough to secure the Publick Interest of the Society, to attain the necessary and most important ends of its Institution." See also note 231 below and C, "Magistrate," "27.," fo. 1r.

${ }^{231}$ This phrasing is very similar to Parker, Discourse, 35: "In that the end of all Government is to secure the Peace and Tranquillity of the Publick; and therefore it must have Power to manage and order every thing that is serviceable to that end." See also C, "Magistrate," "35," fo. 1v.

${ }^{232}$ Parker, Discourse, 29-30: "And the first governments in the world were established purely upon the natural Rights of paternal Authority, which afterward grew up to a Kingly Power by the increase of posterity; and he that was at first but Father of a Family, in process of time, as that multiplied, became Father of a City, or Province: and hence it came to pass that in the first Ages of the World, Monarchy was its only Government, necessarily arising out of the Constitution of humane Nature, it being so natural for Families to enlarge themselves into Cities by uniting into a body according to their several Kindreds, whence by consequence the Supreme Head of those Families must become Prince and Governour of a larger \& more diffused Society." See also C, "29," fo. $1 \mathrm{r}$, and $\mathbf{O}_{\mathbf{1}}$, fo. $5 \mathrm{r}$.

${ }^{233}$ Manuscript damaged; missing letters inferred from context. 
descended wholy to the eldest sonne, or else upon $\left.\mathrm{a}\langle 1\rangle\right|^{234}$ the brothers had an equall power over their respective issues? if the first then the Monarchy is certainely jure naturali, ${ }^{235}$ but then there can be but one rightfull monarch in the whole world i.e. the right heire of Adam, if the second, all governments whether monarchicall or other is only from the consent of the people.

[fo. $8 r$ ]

[blank]

[fo. $8 v$ ]

$\mathrm{Q}^{\mathrm{s}}$ On S.P $\mathrm{P}^{\mathrm{s}}$ discourse of toleration. 69

\section{$\mathbf{O}_{3}$ - "The vulgar are apt..."}

Bodleian Library, MS Locke c. 39, fos 9-10. A pair of queries on Samuel Parker's A Discourse of Ecclesiastical Politie in Locke's hand.

[fo. $9 r$ ]

\section{p. 144}

The vulgar are apt to have wrong opinions in religion be Superstitious \& to have wrong conceits in religion. ${ }^{236}$ Doctrines of religion are very powerfull to incline men to obedience or disturbance. ${ }^{237}$ The opinions in religion influence more forcibly then any, ${ }^{238}$ ergo, it is the magistrates interest to take care what particular doctrines of religion are taught, \& above all things to looke to the doctrines \& articles of mens beleif. ${ }^{239}$ p 144 \$. $3 .^{240}$

There is the same phanatick spirit that mixes it self with all the religions in the world. $153 .^{241}$

\section{Q}

Whether hence it will follow that the magistrate ought to force men by severity of laws \& penaltys to force men to be of the same minde with him in the speculative opinions in religion, or worship god with the same ceremonys? That the magistrate should restraine seditious doctrines who denys but because he may then has he power over all other doctrines to forbid or impose, if he hath not the argument is short, if he hath how far is this short of Mr Hobbs's doctrine?

Whether this Fanatick spirit be not the same passion fird with religious zeale whose phanatick heats he in the same $\S$ accuses of haveing committed such dire outrages massacres \& butchery \& donne such mischeifs among men, \& if it be mixes its self with all religions I desire him to consid examin though he be of the church of England what spirit that is which sets him soe furiously zealously to stir up the magistrate to persecute all those who dissent from him in those opinions or

\footnotetext{
${ }^{234}$ Manuscript damaged; missing letters inferred from context.

235 "jure naturali": by the law of nature.
}

${ }^{236}$ Parker, Discourse, 146: "There is not any vice so incident to the Common People as Superstition, nor any so mischievous. 'Tis infinitely evident from the Histories and Records of all Ages and Nations, that there is nothing so vicious or absurd but may pass for Religion, and (what is worse) the more wild and giddy Conceits of Religion are ever suckt in by the multitude with the greatest passion and eagerness."

${ }^{237}$ Ibid., 144: "Nothing more concerns the Interest of the Civil Magistrate, than to take care, what particular Doctrines of Religion are taught within his Dominions; because some are peculiarly advantageous to the ends of Government, and others as naturally tending to its disturbance."

${ }^{238}$ Ibid., 145: "For seeing Religion has, and will have the strongest influence upon the minds of men."

${ }^{239}$ Ibid., 147: "And therefore it must needs above all things concern Princes, to look to the Doctrines and Articles of mens Belief; seeing 'tis so great odds that they prove of dangerous consequence to the publick Peace."

${ }^{240}$ See also C, "Magistrate," "144" and "p. 144 \&c," fo. 2 r.

${ }^{241}$ See also C, "Magistrate," “153," fo. 2r. 
[fo. 9v]

[blank]

[fo. 10r]

[blank]

[fo. 10v]

Religious

Government $^{242}$

\section{$\mathbf{O}_{1}$ - "Society is necessary ..."}

Bodleian Library, MS Locke c. 39, fos 5-6. A paraphrase of the first chapter of Samuel Parker's A Discourse of Ecclesiastical Politie in Locke's hand.

$[\text { fo. } 5 r]^{243}$

Society is necessary to the preservation of humane nature ${ }^{244}$

Goverment necessary to the preservation of Society The end whereof is peace ${ }^{245}$

One Supreme necessary in every City for the preservation of the government $1^{\circ}$ because there can not be two suprems; $\& 2^{\circ}$ because coordinate distinct powers may command the same person contrary obedience which he cannot be obliged to ${ }^{246}$

This supreme ma is the Civil magistrate ${ }^{247}$

The Civil magistrate must have under his power all that may concerne the end of government i.e. peace. $^{248}$

Religion \& Conscience are more apt to disturbe the peace then even vice itself, $1^{\circ}$ because men are most apt to mistake because backd, with zeale the glory of god \& the good of mens soules it ma martyrdom they make men more resolute confident turbulent \&c. where as vice discoverd is out of countenance ${ }^{249}$ Ergo It is necessary the magistrate should have power over mens consciences in matters of religion. ${ }^{250}$ This power is to be exercised with the most severity \& strictnesse, because ordinary severity will not doe. $^{251}$

Fathers have an absolute power over their children ${ }^{252}$

This paternall power grew into severall monarchys ${ }^{253}$

These monarchs by this paternall right were also preists. ${ }^{254}$

Soveraignty \& preisthood joyntly vested in the same person for first 2500 years $^{255}$

\footnotetext{
${ }^{243}$ All of the text on fo. 5 is written in the left-hand column.

${ }^{244}$ Parker, Discourse, 28. See also C, "Magistrate," “p. 28," fo. 1r.

${ }^{245}$ Parker, Discourse, 28. See also C, "Magistrate," “p. 28," fo. 1r.

${ }^{246}$ Parker, Discourse, 25-6.

${ }^{247}$ Ibid., 27.

${ }^{248}$ Ibid., 27.

${ }^{249}$ Ibid., 18. See also C, “Church," “p 18," fo. 1r; and $\mathbf{O}_{2}$, “p. 12,” fo. $7 \mathrm{r}$.

${ }^{250}$ Parker, Discourse, 18. See also C, "Church," "p 18," fo. 1r; and $\mathbf{O}_{2}$, "p. 12," fo. 7r.

${ }^{251}$ Parker, Discourse, 18. See also C, “Church," “p 18," fo. $1 \mathrm{r}$; and $\mathbf{O}_{2}$, “p. 12," fo. 7r.

${ }^{252}$ Parker, Discourse, 29. See also C, “Magistrate," “29,” fo. $1 \mathrm{r}$; and $\mathbf{O}_{2}$, “p. 29," fo. 7r.

${ }^{253}$ Parker, Discourse, 30.

${ }^{254}$ Ibid., 31.

${ }^{255}$ Ibid., 32. See also C, “Magistrate,” “p. 32 ... ibidem,” fo. 1v.
} 
Ecclesiasticall supremacy exercised by the Jewish Kings though ${ }^{256}$ the preisthood were vested in other persons. $^{257}$

Christ haveing noe temporall power exercised none, nor could giave the magistrate none about his religion which was to be propagated by patience \& submission ${ }^{258}[f o .5 v]$ but instead of civil coercive power to keepe up ecclesiastical discipline there was given the church a miraculous power to punish as well as eject offenders by excommunication this lasted in the church till the magistrate became Christian \& then ceased as noe longer necessary, ${ }^{259}$ because then the government of religion resolved in the magistrate \& was restord though the preists commissioned by our saviour kept the ministerial function \& soe the Christian magistrate hath still again the power over religion ${ }^{260}$

\section{[fo. $6 r]$}

[blank]

[fo. $6 v$ ]

Government $^{261}$

262

Acknowledgment. The manuscript printed in this article was discovered by J. C. Walmsley. The article is a collaboration of the authors, who are grateful for the help provided by Jeffrey Collins, Mark Goldie, Christine Jackson-Holzberg, Duncan Kelly, J. R. Milton, Jacqueline Rose, the Somerset Heritage Centre, and the referees for Modern Intellectual History. The authors are additionally grateful to the University of North Carolina at Chapel Hill for access to the manuscript material presented above and permission to reproduce images of manuscript material in its possession.

\footnotetext{
256"though \{though\}." Duplicated word excised for sense.

${ }^{257}$ Parker, Discourse, 32. See also C, "Magistrate," “32," fo. 1v.

${ }^{258}$ Parker, Discourse, 33-7. See also C, "Magistrate," “32," fo. 1v.

${ }^{259}$ Parker, Discourse, 43-8. See also C, "Magistrate," "48," fo. 1v.

${ }^{260}$ Parker, Discourse, 49-50. See also C, "Magistrate," “49" and “50," fo. 1v.

${ }^{261}$ Endorsed horizontally in pencil on the right-hand side of the page in an unknown early twentiethcentury hand, possibly that of an auctioneer or a dealer in manuscripts.

${ }^{262}$ An illegible pair of words horizontally in pencil on the right-hand side of the page in an unknown early twentieth-century hand different from that immediately above, possibly that of an auctioneer or a dealer in manuscripts.
}

Cite this article: Walmsley JC, Waldmann F (2022). John Locke, Toleration, and Samuel Parker's A Discourse of Ecclesiastical Politie (1669): A New Manuscript. Modern Intellectual History 19, 997-1032. https://doi.org/10.1017/S1479244321000421 